\title{
Celebrating the 95th birthday of Professor Karl S. Pister
}

\section{Part 1 - Biography and tributes}

\author{
Received: 20 August 2021 Accepted: 25 August 2021
}

In Part 1, a biography of Professor Karl Pister is followed by seventeen individual tributes, penned by a diverse group from university presidents to an elementary school teacher, with the longest tribute by Dr. Sheila Humphreys focusing on Professor Pister's endeavor to increase the enrollment of minorities in engineering.

\section{Biography of Professor Karl S. Pister}

by Professor Mark Austin

\section{Tributes to Professor Pister}

Professor Thomas J.R. Hughes

University-of-the-Pacific President Pamela Eibeck

University-of-Maryland President Darryll Pines

Professor Alice Agogino

Professor J. Tinsley Oden

Ms. Lola Martin-Atilano

Ms. Billie Greene

Professor Stein Sture

Professor Constance Lütolf-Carroll

Professor Ekkehard Ramm

Dr. Paula Hawthorn and Dr. Barbara Simons, President of the ACM

Cooper-Union Vice President Antoinette Torres

Professor Carlos Felippa

Mr. Brant Smith

Professor Peter Pinsky

University-of-California-at-Davis Chancellor Gary May

Dr. Sheila Humphreys 


\title{
Celebrating the 95th birthday of Professor Karl S. Pister
}

\author{
A biography by Professor Mark Austin \\ With contribution and editing by Professor Loc Vu-Quoc
}

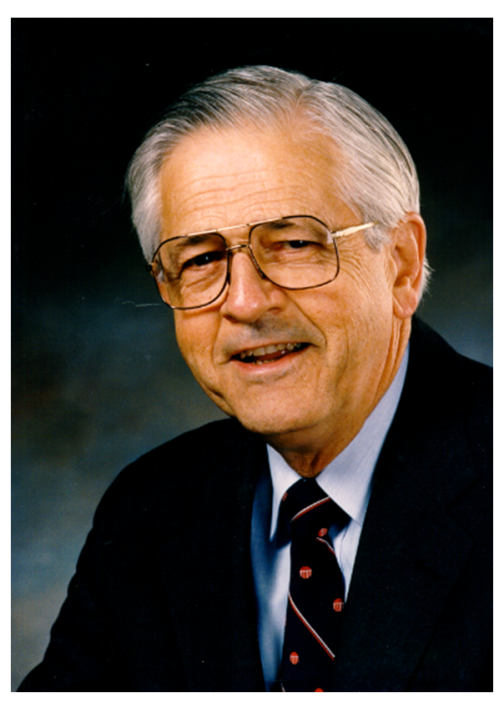

Chancellor and Dean Karl S. Pister

Karl Stark Pister was born June 27, 1925, in Stockton, California. He graduated from Stockton High School as class valedictorian in 1942, and from UC Berkeley with a BS in Civil Engineering in 1945. After a short stint in the Naval Reserve and an assignment to Okinawa, Japan, during World War II, he commenced studies at Berkeley during the fall of 1946, and graduated with an MS in Civil Engineering in 1948. This was followed by a $\mathrm{PhD}$ in Theoretical and Applied Mechanics from the University of Illinois at Urbana-Champaign in 1952.

When Pister was hired at UC Berkeley in 1952, he initially conducted research on material properties of Portland Cement Concrete and the behavior of torpedo nets. For this early research work, he received the Wason Medal for Research, awarded by the American Concrete Institute. During the late 1950s he also began a multi-decade association with Lawrence Livermore National Labs.

Over the next two decades, he served as Vice-chair of the Civil Engineering Department (1964-65), Chairman of the Division of Structural Engineering and Structural Mechanics (1970-71), Chairman of Committee on Educational Policy at Berkeley (1972-73), Senate Policy chair and Academic Senate, Berkeley Division, vice chair (1976-78), and Vice chairman and chairman of the nine-campus Academic Council and Assembly of the Academic Senate (1978-1980).

Pister was appointed Dean of the College of Engineering in 1980, a position he held for ten years. From 1985 to 1990, he was the first holder of the Roy W. Carlson Chair in Engineering. From 1991-1996 he served as Chancellor, UC Santa Cruz. He then returned to Berkeley to work as Vice President for Educational Outreach in the UC Office of the President (1999-2000) and to chair the task force on upgrading California Memorial Stadium (2004-2012). Throughout these many roles, he is well known and respected for leading by example, and his passionate commitment to promoting social justice.

The American Society for Engineering Education presented him with the Vincent Bendix Award for Minorities in Engineering, and the Lamme Medal, the highest honor bestowed by the society, for his contributions to engineering education. He is also a Fellow of the American Academy of Mechanics, the American Society of Mechanical Engineers, the American Association for the Advancement of Science and an Honorary Fellow of the California Academy of Sciences.

Pister is a member of the National Academy of Engineering (1980) and a Fellow of the American Academy of Arts and Sciences. He is the recipient of the Berkeley Medal (1996) and the Presidential Medal of the University of California (2000). In 2006, The California Alumni Association named him Cal Alumnus of the Year.

Karl Pister married Rita Olsen in 1950. They have four daughters and two sons. 


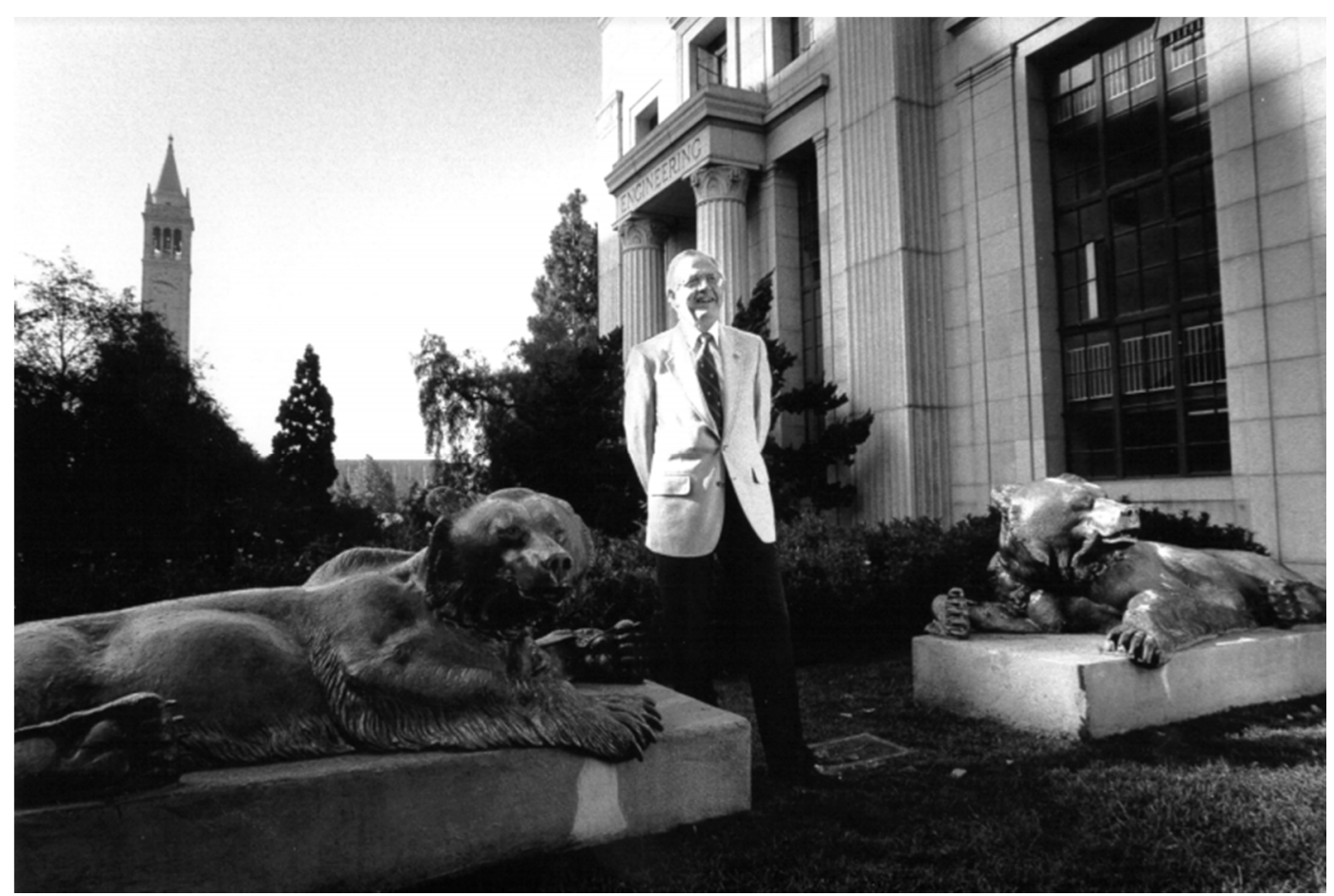

Dean and Roy Carlson Professor Karl Pister in front of the Dean's office building (right) with the Campanile (left) on the Berkeley campus in the background.

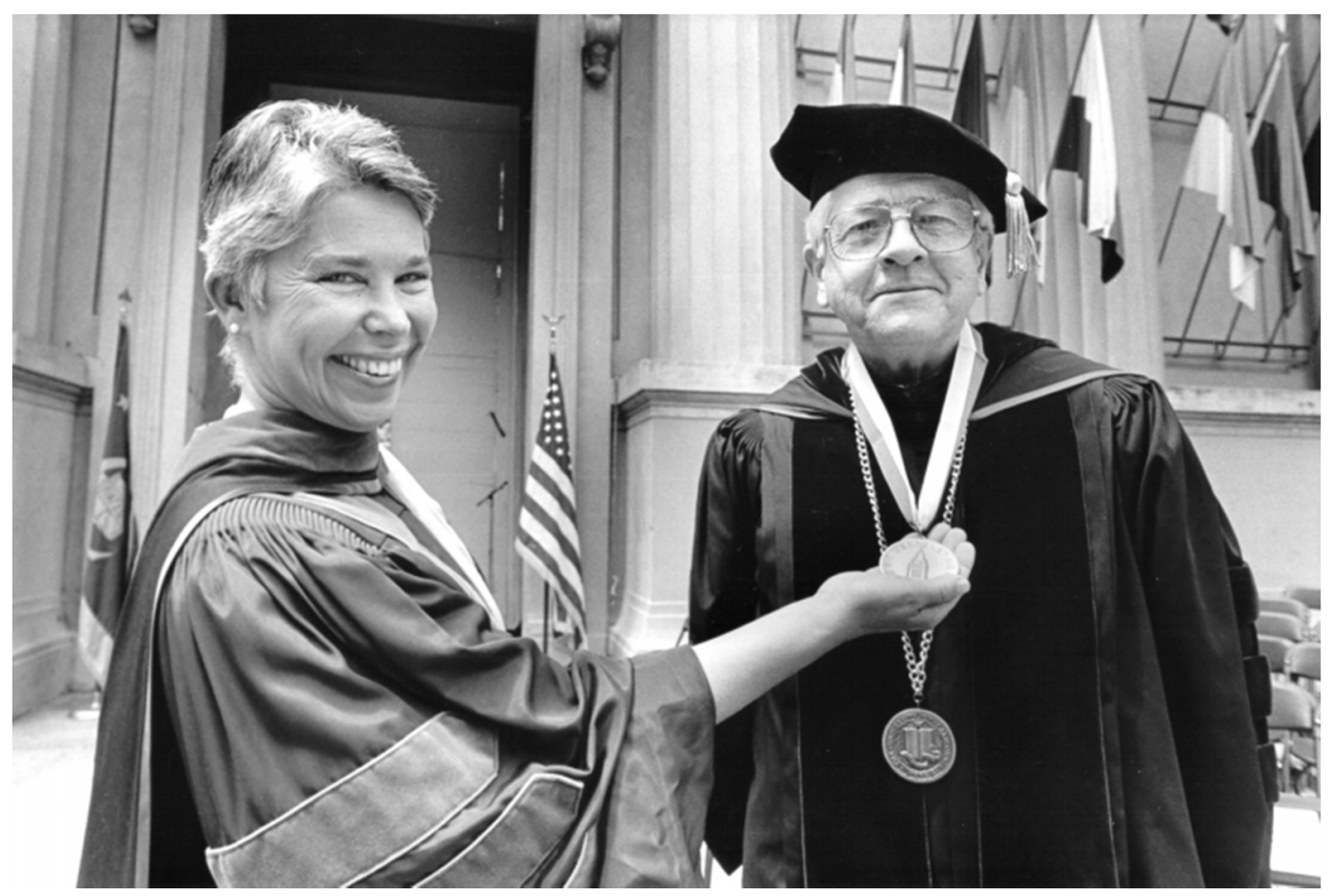

Professor Karl Pister received the Berkeley Medal on 1996 May 18, Saturday, shortly after he stepped down from the chancellorship at UC Santa Cruz, from then Berkeley Provost Carol T. Christ (now UC Berkeley Chancellor). 


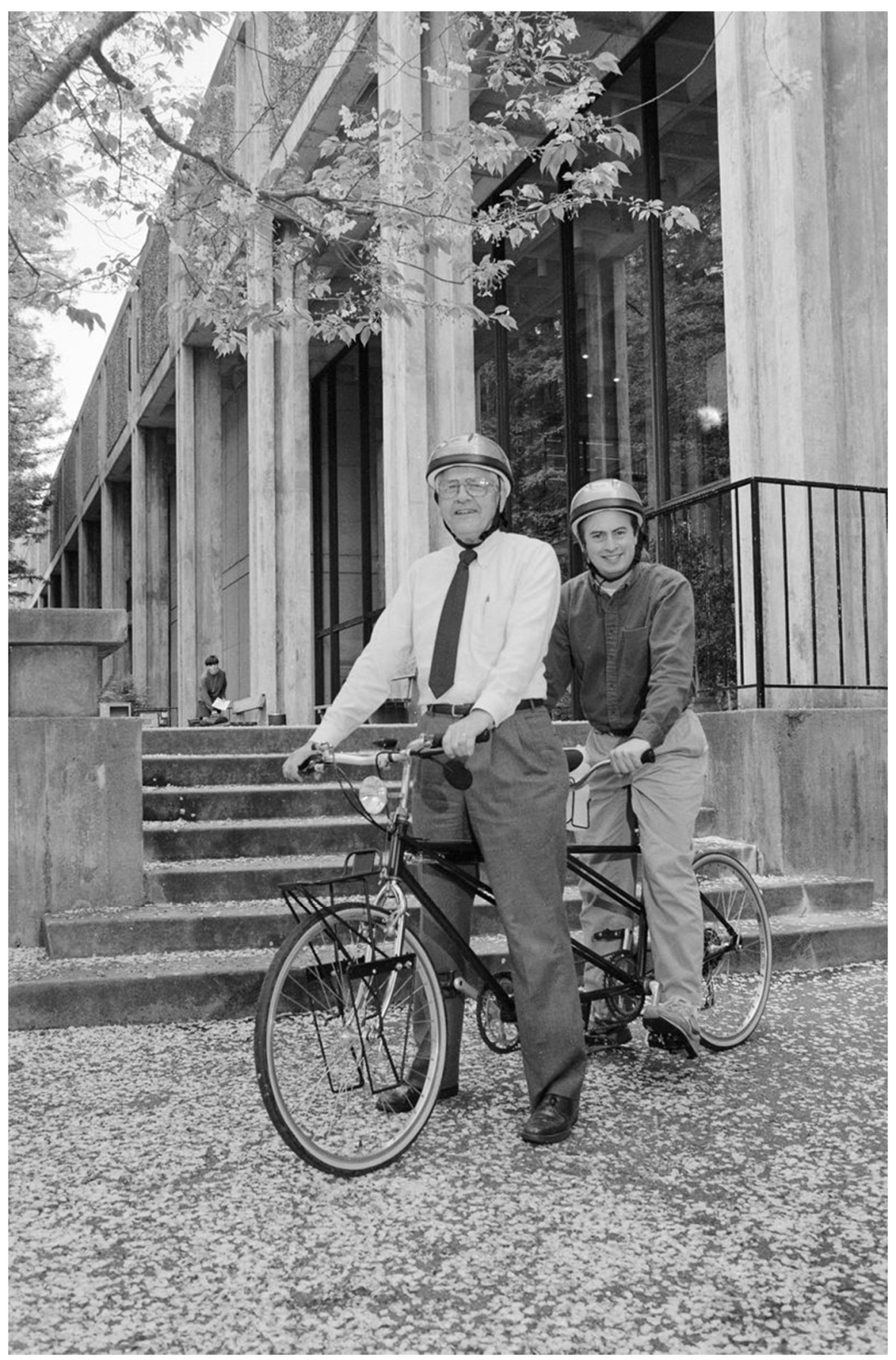

University of California at Santa Cruz Chancellor Karl Pister on a tandem bicycle with undergraduate student and Student Union Assembly Chair Brant Smith on 1992 April 13. This photo was taken as part of a campaign to encourage riding bicycles to school or to work.

(c) The Regents of the University of California. Courtesy Special Collections, University Library, Photography Services, University of California, Santa Cruz. 
Dr. Mark Austin

Department of Civil and Environmental Engineering, University of Maryland at College Park

austin@umd.edu

Website: http://www.isr.umd.edu/ austin (Internet archived on 2021.07.20)

Editor's note: “The Berkeley Medal was established in 1981 as UC Berkeley's top honor. On very rare and special occasions, it is bestowed on individuals whose exceptionally distinguished contributions to society advance the university's ideals and goals and whose careers have benefited the public beyond the demands of tradition, rank, or direct service to Berkeley." Among the past recipients were Corazon Aquino, Kofi Annan, Michelle Bachelet, Jimmy Carter, the 14th Dalai Lama Tenzin Gyatso, to cite a few.

Mr. Brant Smith in the photo taken at UC Santa Cruz above contributed a tribute to Professor Pister further below.

The Karl Pister Berkeley Oral History (Internet archived on 2021.03.09) contains extensive biographical details, with a biographical timeline given in a separate document at the end of Part 3 in this special issue.

Photos in this special issue came from either the Pister family photo collection, or from individual participants. Photo credits were given where applicable. LVQ 


\title{
Celebrating the 95th birthday of Professor Karl S. Pister
}

\author{
Tribute by Professor Thomas J.R. Hughes
}

I first heard of Professor Karl Pister from Dr. John Baylor, a scientist in the Research and Development Laboratory, General Dynamics/Electric Boat Division (GD/EB) in Groton, Connecticut, in 1968. I had joined GD/EB in 1967 and was befriended by John, who was considered the Laboratory "resident genius." Sometime in 1968 I decided that I wanted to return to school and obtain a $\mathrm{PhD}$, and, in particular, I wanted to do it at the University of California at Berkeley, where John had done his PhD. Karl Pister was John's $\mathrm{PhD}$ supervisor and John was enormously enthusiastic about Karl, the engineer and the man, and insisted that Karl was the ideal supervisor for me. So, I wrote to Karl and he responded with a handwritten letter inviting me to join what was known at the time as the "Pister Research Machine." That was a thrill and the beginning of a dream come true.

In August of 1969 I left Connecticut and drove across the country to Berkeley, and after I got settled, I went to Davis Hall to let Professor Pister know I had arrived. I knocked on his door, he told me to come in, and I entered and introduced myself. He said, "who are you?" I explained I was the guy from GD/EB that he invited to join his group as a research assistant. He said "oh," which amounted to an inauspicious start as a member of the Pister Research Machine. After that, it got more interesting and better. In discussions with Karl, I told him I already knew quite a bit about the finite element method from my work at GD/EB, but what I wanted to focus on in my studies was mathematics and mechanics, and perhaps get back to the FEM toward the end of my degree. Because both my degrees were in mechanical engineering and I had taken some additional graduate courses in mechanics at the University of Connecticut while working at GD/EB, Karl said that I should major in Engineering Science, which would give me maximum latitude to design my own graduate program. Karl approved my proposed course programs every quarter and I had the time of my life studying everything I wanted to study. I think if my wife had not gotten increasingly worried that I might become a perpetual student and had not urged me to finish in the strongest possible terms, I might still be taking courses at Berkeley to this day. Karl understood the intellectual journey I wanted to pursue and gave me his full support. I had never experienced anything like the freedom and autonomy that Karl gave me during my previous education. I would not be who I am today without Karl's encouragement to broaden my horizons, and do exactly what I wanted to do, and I am deeply indebted to him for the opportunities he gave me.

After I finished my PhD degree and began teaching at Berkeley, Karl invited me to co-teach one of the graduate mechanics courses with him. I suggested that this would be an opportunity to combine mechanics with modern mathematics relevant to computation and he enthusiastically agreed. I wrote some notes for my parts of the course and off we went. I did not retain copies of my notes from that course but was reminded of them by Professor Bob Taylor, who showed a sample from them during a plenary lecture he gave a few years ago, entitled "My Fifty Years in the Finite Element Method," at a US National Congress on Computational Mechanics. Bob described the notes as emanating from the first Computational Mechanics course ever given at Berkeley.

Karl supported me from the time I arrived at Berkeley and throughout my entire academic career. He has been my role model in the way I pursue $\mathrm{PhD}$ education. What he did for me, I try to do for those students that join my research group, giving them the encouragement and support to do what they want to do. I believe it is the best guidance one can give intellectually ambitious, self-motivated students. I learned that from Karl. 
Karl Pister changed my life and set me on the direction that I took in pursuit of my life's work. I learned a great deal of mechanics from him, but much more about how to conduct myself as an academic and as a person. He was indeed the perfect mentor for me. I know too that my experience was similar to that of the many other students and individuals he guided throughout his long career.

Dear Karl, thank you so much for all you have done for me, and best wishes to you on your $95^{\text {th }}$ birthday.

Dr. Thomas J.R. Hughes

Peter O'Donnell Jr. Chair in Computational and Applied Mathematics

Professor of Aerospace Engineering and Engineering Mechanics

hughes@oden.utexas.edu

tjr_hughes@hotmail.com

Web page: http://users.oden.utexas.edu/ hughes/ (Internet archived on 2021.04.15)

Wikipedia: 'Thomas J.R. Hughes' (Version 19:37, 23 June 2021)

Editor's note: For the beginning of the lecture notes that Professor Hughes developed to co-teach with Professor Pister the first computational mechanics course at Berkeley, see the Memory-lane section in Part 3 of this special issue. LVQ 


\section{Celebrating the 95th birthday of Professor Karl S. Pister}

\section{Tribute by University-of-the-Pacific President Emerita Pamela Eibeck}

Happy Birthday, Karl! You deserve accolades for your contributions as a brilliant scholar and adept administrator. But from my perspective, your most important legacy is the number of people whose lives you touched with your wisdom, compassion and support. I am one of those people.

I remember arriving at UC Berkeley in 1985 as an unsure Assistant Professor. I was the fifth female faculty member in the College of Engineering of nearly 300 faculty. Needless to say, I did not fit in. When we met later that year, I was surprised to discover that Dean Pister was the father of my college friend, Jacinta. Your warm greeting and sincere concern about my well-being let me know I could turn to you if I needed guidance.

And you were there for me when I was considering quitting my job to spend more time with my new baby. I had just received tenure and promotion, and instead of enthusiasm for my future at Cal, I was daunted at the prospect of balancing being a mother and a successful Berkeley prof. You and I briefly discussed my dilemma. Soon afterwards, you wrote me a beautiful handwritten letter that a father would write to his daughter, validating my conundrum and supporting whatever decision I made. You and the ME department allowed me to work part time for nearly 5 years while I raised my two young children - a solution for which I will always be grateful. Your letter still resides in my small collection of treasured communications.

You also left an indelible mark on me as a future academic administrator by your advocacy of a new set of principles for promotion and tenure at UCB. I was intrigued by your vision that scholarship should be defined not only as the discovery of new knowledge, but also as the creative application of knowledge or the advancement of teaching (as articulated by Ernest Boyer's Scholarship Reconsidered (1990)). While your committee's recommendations were not adopted by UC Berkeley, they influenced my work as an academic leader over the 25 years after I left Cal.

Thank you for being a mentor and frequent reference as I moved to various universities. You were prescient with your note congratulating me for becoming dean of engineering at Texas Tech, stating "But Texas, Pam - really!?" Little did I realize the culture clash a family of Californians would experience in Texas. But it was fitting that while I was in Texas - where nothing stands in the way of a larger and grander football stadium - you were dealing with tree-sitters resisting the expansion of Cal's stadium!

Bill and I were delighted to return to California to be President at University of the Pacific in your hometown of Stockton. Having you speak at my Presidential Inauguration was deeply meaningful to me. You spoke of the ways universities can lift up their communities, reflecting your work as Chancellor at UC Santa Cruz as well as your affection for Stockton and the Central Valley. After ten years as president, I hope I lived up to your expectations of leaving Stockton, as well as UOP, a better place.

You have been a treasured friend and mentor, Karl. You deserve many years ahead surrounded by the many people that love you.

Dr. Pamela A. Eibeck

University of the Pacific President Emerita (Internet archived on 2021.06.23)

pameibeck@gmail.com 


\section{Celebrating the 95th birthday of Professor Karl S. Pister Tribute by University-of-Maryland President Darryll Pines}

When I was a student at the University of California at Berkeley (Cal) in the 1980s, I met Dean Karl Pister maybe once at a reception in the Berkeley Bechtel Library.

As I have reflected about my own personal journey to the position of President of the University of Maryland, College Park (UMD), there is no question that I would not be where I am today if it were not for the Minority Engineering Program (MEP) at UC Berkeley. The program gave me an opportunity to hone my math, science and engineering skills, while building relationships that would last a lifetime.

First, I was admitted to UC Berkeley in 1982 and I was strongly encouraged to participate in MEP's Summer Bridge Program. This is where I met two very important and special staff members of the MEP program. Their names were Ms. Antoinette Torres and Mr. Charles Tunstall. These two individuals were critical to the success of so many students in STEM disciplines at UC Berkeley. They were mentors, educators, and advisors to all MEP students and ensured our collective success in our respective programs.

The other group that I am deeply grateful to have benefited from were my fellow MEP cohort of students including Milton Howard, Warren and Adrienne Hogg, Curtis Broome, Morgan Edwards, Ken Osbourne, Clenita Justice, and so many others. This group bonded as part of MEP and has stayed a part of my Cal alumni network for almost 40 years.

Thus, I am one of many proud MEP participants who owes a debt of gratitude to the program.

Dr. Darryll J. Pines, Ph.D., NAE (He/Him/His)

President of the University of Maryland

Glenn L. Martin Professor of Aerospace Engineering

pines@umd.edu

Homepage $\mid$ Office of the President (umd.edu) (Internet archived on 2021.06.05)

\section{MARYLAND \\ UMD.EDU/4MARYLAND}

Wikipedia: 'Darryll Pines' (Version 01:50, 20 June 2021)

Editor's note: For more details on the Minority Engineering Program at Berkeley and some of the people mentioned above---particularly Ms. Antoinette Torres, Mr. Charles Tunstall, and Milton Howard---the reader is referred to the tribute by Ms. Antoinette Torres and the long and detailed tribute by Dr. Sheila Humphreys. See also the tribute by the University-of-California-at-Davis Chancellor Gary May. LVQ 


\title{
Celebrating the 95th birthday of Professor Karl S. Pister
}

\author{
Tribute by Professor Alice Agogino
}

I was hired as an Assistant Professor in Mechanical Engineering (ME) at UC Berkeley on July 1, 1984. Karl Pister was Dean of the College of Engineering then and he made a point to meet with me several times during my first year. I was fortunate to be Karl's mentee so early in my career at UC Berkeley.

I recall Karl visiting my office and asking his advice on an Artificial Intelligence (AI) course I wanted to teach around 1985. I was worried ME faculty and students wouldn't think the course would be MEenough.

Karl's research was in the early days of finite-element analysis. He said the finite-element subject was criticized as a course offering as it was too mathematical and not a good subject for engineers. He compromised and started a research seminar on the subject. The rest is history as finite-element analysis is now an essential part of Civil Engineering.

I started my "expert systems" AI course with a Bayesian emphasis, and it had a full house for two decades. In addition to ME graduate students taking my course, I had students in other engineering departments as well, such as EECS and IEOR. Dr. Gary May, now Chancellor of UC Davis and former Dean of Engineering at Georgia Tech, was in one of the early versions of the course. ${ }^{1}$ I quit teaching the course as other departments were offering Bayesian-oriented AI courses, an approach which is now standard in AI and machine learning. So, I thought there was no need to continue and wanted to spend more time on other initiatives.

There are many things to admire about Karl Pister. Perhaps the most I value was his unyielding support for the role of teaching and promoting diversity and inclusion in higher education. As Dean he founded the Center for Underrepresented Students (CUES), for which I was to manage as Associate Dean for four years.

Karl was instrumental in recognizing the importance of the scholarship of teaching in faculty promotion cases in the Report of the 1991 Universitywide Task Force on Faculty Rewards, often referred to as the Pister Report. The report emphasized the need to "restore a more appropriate balance among the traditional categories of scholarly activity of the faculty, and we must exercise more judiciously the flexibility in evaluation of faculty performance that is currently available in our Academic Personnel Manual, yet infrequently utilized" (cover letter by Karl Pister, June 26, 1991).

Karl championed diversity and inclusion as specific responsibilities of all faculty, and it showed as one the recommendations: "Implementation of diversity- and equity- oriented goals of the University is a shared responsibility among all faculty, and faculty should be encouraged to pursue these activities and be rewarded for meritorious achievement wherever engaged in the 'proper work of faculty members'. " After much deliberation among the faculty Senates, this recommendation led to specific language about diversity and inclusion in faculty promotions.

\footnotetext{
${ }^{1}$ Editor's notes: The University-of-California-at-Davis Chancellor Gary May contributed a tribute further below in the present section, and had a photo with Professor Pister and Dr. Humphreys in the Supplements. LVQ
} 
I see Karl Pister as a role model for all academics. He believes the development of people is one of the most important missions we have. Even in retirement, Karl Pister continues to pursue this mission to the benefit of his individual mentees, the UC Berkeley community and the engineering profession.

Dr. Alice Merner Agogino

Roscoe and Elizabeth Hughes Professor of Mechanical Engineering

Product Design Concentration Founder and Advisor, MEng Program

Chair, Development Engineering Graduate Group

Education Director, Blum Center for Developing Economies

See our new Master of Development Engineering (Internet archived on 2021.05.01)

Office: Blum Center for Developing Economies

Blum Hall 200E

http://www.berkeley.edu/map/?blum

510-666-3704 (office phone)

510-643-5316 (receptionist)

University of California at Berkeley

Berkeley, CA 94720

agogino@berkeley.edu

https://me.berkeley.edu/people/alice-m-agogino/ (Internet archived on 2021.06.13)

Twitter: http://twitter.com/agogino

My pronouns are she, her, hers. (What's this?)
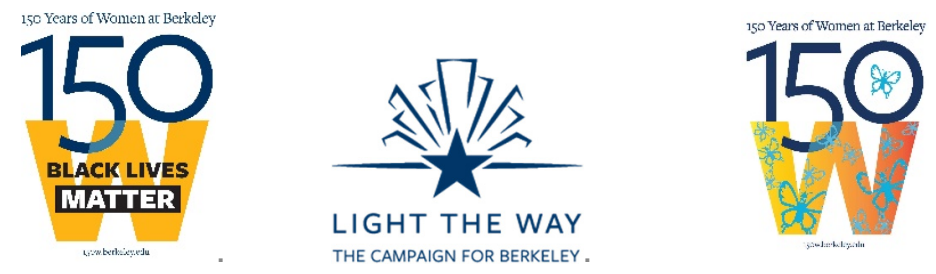

Wikipedia: 'Alice Agogino' (Version 14:38, 29 May 2021) 


\title{
Celebrating the 95th birthday of Professor Karl S. Pister
}

\author{
Tribute by Professor J. Tinsley Oden
}

\author{
A Reminiscence of a Time with Karl
}

Dear Karl,

I am so honored that I have this chance to formally congratulate you on your special birthday and to tell you that it has been my privilege to know you and follow your amazing career and to witness your long list of accomplishments over many decades. You have made stellar contributions to science, engineering, academia, and to the leadership of major educational institutions that are legend and are hugely appreciated by all of us in academia and computational science.

One of our most memorable interactions and collaborations was at the NATO Advanced Study Institute held in Laboratory Nacional de Engenharia Civil in Lisbon, Portugal during September 1-17, 1971. It was a wonderful intense meeting devoted to Finite Element Methods in Continuum Mechanics, organized by Eduardo R de Arantes e Oliveria, Director if the Laboratory, and attended by around 100-150 academics, students, and engineers from all over the western world Its stated purpose was to 1) present a modern and synthetical description of the analytical models of continuum mechanics, 2) to present the theoretical foundations of finite element methods, 3) to give information on recent research on finite elements in structural mechanics and other areas, and 4) to bring together specialists working in finite elements and continuum mechanics

There were seven lecturers who gave detailed lectures during the course of the institute: Karl Pister, of course, J. T. Oden, Eduardo R. Arantes e Oliverira, B. Fraeijs de Veubeke, O. C. Zienkiewicz, Ray Clough, and Pedro Marcel Karl gave a lengthy lecture over several hours on the foundations of continuum mechanics that set the stage for the rest of the course. I gave five lectures over a week on finite element methods for problems in fluid mechanics, finite thermo-visco-elasticity, and nonlinear continuum mechanics. Olivera gave lectures on early versions of the mathematical theory of finite elements including a priori error estimates; Fraeijs de Veubeke gave a series of lectures on duality principles in structural analysis and elastodynamics, his speciality; Zienkiewicz lectured on isoparametric elements, weighted residual methods, and applications to porous media; Clough talked on structural dynamics, vibration analysis and numerical integration; and Marcel lectured on problems of large deformation and structural stability analysis. It was a comprehensive course on the subject given in the relatively early days of finite elements in continuum mechanics.

The entire set of lectures was published in book of over 560 pages, compiled and edited by myself and Oliveria, and published by the UAH Press of the University of Alabama in Huntsville, where I held a faculty position at the time. You can still find the book online if interested. During this wonderful meeting, I grew to greatly admire and respect you for your knowledge, kind demeanor, and humor, and we have become lifelong friends. I remember you scolded me jokingly for using too many polynomial approximations in some of my methods, saying the real world doesn't always obey polynomials. My only retort was to quote Weierstrass' Theorem: Any continuous real-valued function on a compact interval can be uniformly approximated by polynomials. 
Karl, once again, I wish you a healthy and happy birthday and look forward to many more with you.

Dr. J. Tinsley Oden

Founding Director, Oden Institute for Computational Engineering and Sciences

Cockrell Family Regents Chair in Engineering

Professor of Aerospace Engineering and Engineering Mechanics

Professor of Mathematics

Professor of Computer Science

The University of Texas at Austin

oden@oden.utexas.edu

Web page: https://www.oden.utexas.edu/people/85/ (Internet archived on 2021.02.18)

Wikipedia: 'J. Tinsley Oden' (Version 02:30, 25 June 2021) 


\title{
Celebrating the 95th birthday of Professor Karl S. Pister
}

\author{
Tribute by Ms. Lola Martin-Atilano
}

Arranged and edited by Professor Loc Vu-Quoc

The Karl S. Pister Leadership Opportunity Award changed my life forever. I was permanently disabled due to an accident. This scholarship, Dr. Pister's support and guidance made it possible for me to get an education and a wonderful profession. Thank you Dr. Pister.

It's hard to write about my admiration for Dr. Pister in a couple of sentences. I love that man. Had I never met him, I don't know what would have become of me and my kids.

Ms. Billie Greene had a great part in my education, too. I admire Billie so much for all the help that she gave me while at UCSC.

Dr. Pister and Ms. Greene helped shape my new life.

Thank you from the bottom of my heart.

Ms. Lola Martin-Atilano

Kindergarten teacher (Internet archived on 2021.06.05)

Freedom Elementary School, Freedom, California (Internet archived 2020.08.10)

Freedom Elementary (schoolloop.com) (Internet archived on 2021.06.05)

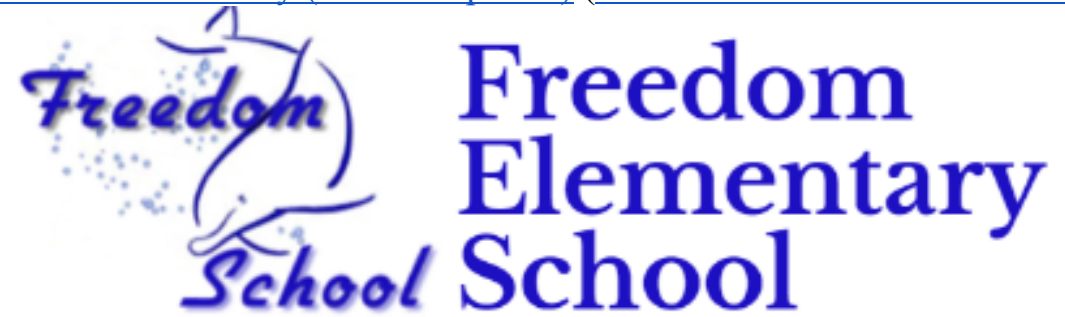

lola_atilano@yahoo.com

Editor's note: When she was a kid, Ms. Martin-Atilano marched with her father, a strawberry sharecropper, and 'Cesar Chavez' (Wikipedia version 19:58, 19 May 2021), an American labor leader and civil rights activist, who co-founded the precursor of the United Farm Workers (UFW) labor union, and who was posthumously awarded the Presidential Medal of Freedom in 1994. Every year, the Freedom Elementary School honors "Cesar Chavez by recognizing one of its own teachers for performing community service". Ms. Martin-Atilano was recognized for this honor; see the article "Freedom Elementary School honors UFW activists," Santa Cruz Sentinel, 2018.09.11 (Internet archived on 2021.06.05). Ms. Martin-Atilano was a Joel Frankel scholarship awardee in 1995-96. See also the tribute by Ms. Billie Greene in this issue. LVQ 


\title{
Celebrating the 95th birthday of Professor Karl S. Pister
}

\author{
Tribute by Ms. Billie Greene
}

It is no exaggeration to say that Karl has had a profound impact on my life, not just my career. He has always led by example and is kind, compassionate, respectful of others, and generous with praise, and I have strived to develop those traits in myself.

Karl "inherited" me when he was appointed Dean of the College of Engineering in 1980. We were first introduced at a dinner honoring the newly completed Bechtel Engineering Center. I was secretary to Dean Kuh at the time and Karl's appointment hadn't been announced, so his greeting, "I think we'll be seeing a lot of one another in the days ahead," was, by necessity, circumspect, and provided insight into his understanding of both discretion as well as good manners.

Upon meeting officially, we learned quickly that we held similar values: treating others with respect; honesty; commitment to family, friends and the university; and fulfilling our responsibilities with integrity and compassion. We also learned that we were both from Stockton, California, and had both attended YMCA camp at Lake Alpine, in the Sierra's. This bit of shared history seemed like "the icing on the cake" and sealed our bond.

Not long after that meeting, Karl dropped some paperwork off at my home (He was on sabbatical leave fall quarter, 1980), and met my the 12-year- old daughter for the first time - via the mechanism of a "hamster ball" that was rolling right toward his feet! He watched her grow up over the next 10 years, eventually graduating from $\mathrm{Cal}$ and setting off for Japan for her first teaching position. Karl often told the staff that "family comes first" and Judi Tessier (his former secretary at UC Santa Cruz) recently recollected a time her son called the Chancellor's Office when Judi was taking dictation when the receptionist knocked politely and conveyed the message that her son was on the phone and needed to talk to his mother. Without hesitation, Chancellor said, "Take the call - the dictation can wait." Sometime later, Judi overheard her son tell a friend, "My mother thinks I'm important. She always takes my calls."

Karl always treated everybody with respect and dignity. Staff were aware of the esteem in which they were held. As Toni Torres said about her interactions with then-Dean Pister, "I was heard and valued and engaged in a purpose that is with me today." His long-time secretary in the Dean's office, Marilyn Witbeck, wrote something similar: "The Pister years were the best. I remember how special it felt to go into his office for a meeting in that corner couch and chair-it was professional intimacy, physical closeness that inspired my best thinking and listening." In her tribute upon his retirement from UCSC, one long-term member of the Chancellor's Office wrote, "He's a real human being - friendly, approachable and caring. He's also the first Chancellor I've known who remembers the names of all the staff people in the Chancellor's and Executive Vice Chancellor's office!" In fact, he never walked by the receptionist's desk in the morning or evening without saying good morning and good evening.

Furthermore, Karl was generous with 'thank you's.' A couple of examples come to mind. While Dean of the College of Engineering, he attended quarterly meetings of the 'Big 10 Deans'. In preparation for one particularly important meeting, the staff had worked hard to compile a statistical package that included both enrollment and budgetary information. Upon returning from that meeting, he asked that the staff convene in the reception area at 9a.m. Anxiously, people gathered, expecting bad news but, instead, heard his 
gratitude for the material they had provided, indicating he was the best prepared dean at the meeting thanks to their hard work. On another occasion, returning to the Dean's office after an off-campus luncheon, he realized he was driving Mrs. Pister's car and didn't have his campus parking permit with him. With a smile, the attendant in the parking kiosk at the entrance to campus graciously issued him a temporary permit. The moment he sat down at his desk, he dictated a Thank You note to her (he had asked her name) with a $\mathrm{cc}$ to her supervisor, thanking her for her professional and courteous treatment (Many of us cherish similar notes, received over the years.) Dean/Chancellor Pister frequently referred to the important role "gatekeepers" (all of us) played in representing the face of the College/University to others, whether they be students, faculty, parents or the general public.

In 1993, Chancellor Pister founded the Leadership Opportunity Award Program at UC Santa Cruz to bring outstanding (though disadvantaged) transfer-eligible students from 13 area community colleges to the campus. (A tribute from Ms. Lola Martin-Atilano, a 1993-94 recipient, is included in this special journal edition.) Approximately 350 recipients have graduated, to date. Helping design and implement the LOA was one of my most cherished assignments because, as Chancellor Pister stated, it would have a significant long-term impact on the lives of many people in addition to the recipients, themselves.

In spite of the long hours and demands of administrative work, Karl Pister could (and did) have fun. One of my favorite images of him is from a dinner hosted by Chancellor and Mrs. Pister in my honor in 1996. Chancellor Pister was a "good sport" and had a wonderful sense of humor. He (and all the guests) was wearing a strand of pearls and pearl earrings in recognition of the "iconic" pearls I was famous for wearing. (Wouldn't you know, the latch on my own pearls had broken while dressing for the party, and I was the only person NOT wearing pearls that evening.)

Another image that pops into mind is Dean Pister answering the phone at the reception desk in the College of Engineering, while the staff attended an end-of-year holiday party. It was a gift he was delighted in giving. He was also delighted in hearing the surprised tone of voice at the other end of the line when the caller learned she was speaking with the dean!

Many unforgettable images crowd through my mind as I think back on the 15 memorable years we shared. All of them lead to a Karl Pister analogy: If the College of Engineering and UC Santa Cruz were people, Karl Pister would be their hearts.

Ms. Billie Greene

Secretary to the Dean, University of California at Berkeley (1972 - 1983)

Assistant to the Dean, UC Berkeley (1983 - 1990)

Executive Assistant to the Chancellor, UC Santa Cruz (1990 - 1996)

freesias2000@yahoo.com 


\title{
Celebrating the 95th birthday of Professor Karl S. Pister
}

\author{
Tribute by Professor Stein Sture
}

It is an honor and privilege to participate in the celebration of Karl S. Pister's 95th birthday and to contribute a brief narrative of memories and interactions that span nearly four decades. We first met at a small NSF sponsored workshop on the behavior of high-strength concrete held in Chicago in the late 1970's arranged by faculty at Northwestern University, with focus on the Water Tower building that had just been completed, and which was the first use of this relatively new material in a major construction project. There were lively discussions involving some strong personalities, and I vividly recall Karl's excellent insights and calm demeanor and deliberate observations and opinions on matters involving behavior of concrete, although I thought he was an all-out focused finite element analyst and scholar. It soon became clear that Karl was a true renaissance - engineer with very broad and deep knowledge of engineered systems and materials of all kinds. Heck, after all he was Dean of Engineering at that point, and that is of course what one would expect engineering deans to know!

The most frequent interactions I had with Karl Pister were at many technical and scientific society conferences and committee meetings, where we were both involved, and where Karl frequently presented keynote lectures. His range of interests and appropriate focus on general circumstances were always amazing. I recall one instance at a Joint ASCE-ASME-SES Mechanics Conference held in San Diego, where he moved with great facility from a very formal technical presentation to a highly entertaining lunch talk within a very short time. He did a very similar thing at an early US National Congress on Computational Mechanics held in Boulder, where he entertained conference steering committee members to a grand and lucid, yet detailed journey through the history of finite element developments from the beginnings to the present day. Karl was always diplomatic in open discussions, even those involving controversial subjects, yet outspoken and firm when necessary. He was always considerate and supportive of junior mechanicians and engineers, even when presentations were more than wobbly. Karl has always had a great sense of humor, and I recall an incident at a very memorable conference held at the University of Arizona in the early-mid 1980's (see photo in the Memory-lane section), where the reception and dinner included lively discussions punctuated by a dance maneuver performed by a very senior (now deceased) faculty member from Stanford. Karl had clearly not forgotten specifics in his post-dinner talk, where he made a humorous reference to the previous dance display, by saying that "Prof. L. seems to have finally understood the principles of finite plastic rotations....", which made the crowd roar in laughter.

There is so much to write but let me conclude with a brief story involving Karl S. Pister's interests in international travel, where I especially recall Karl's and his wife's plans to travel along the Norwegian coast during summertime on a combined passenger-cargo ship starting from Bergen, past the North Cape and all the way to Kirkenes on the Russian border. He apparently enjoyed it immensely since he would often refer to the experience when we later met. Let me conclude by wishing Karl all the best! It has been a privilege and honor to know you all these years!

Dr. Stein Sture

Vice Chancellor for Research Emeritus

Huber and Helen Croft Professor of Engineering and Applied Science Emeritus

Laboratory for Atmospheric and Space Physics

University of Colorado, Boulder

Stein.Sture@colorado.edu

Website: http://www.colorado.edu/ceae/stein-sture (Internet archived on 2021.01.28) 


\section{Celebrating the 95th birthday of Professor Karl S. Pister}

\section{Tribute by Professor Constance Lütolf-Carroll}

Dr. Karl Pister has been my mentor, friend, and counsellor for 45 years. It is with great joy that I wish him all the best for his $95^{\text {th }}$ birthday. I am very honored to be asked to write this tribute and to reminisce about some of the adventures that Karl and I have had together.

Karl was my professor for CE-130 Mechanics of Materials in Winter 1976. As a pre-law major coming from San Diego State University, I transferred into Cal's civil engineering program in my junior year. Basic engineering concepts were at first a struggle for me. I knew about stress and strain in human, psychological terms, but found it difficult to apply these concepts to concrete or steel. During the first week, I went to visit Karl during his office hours, and I vividly remember sitting by his desk as he patiently drew a grid on a large pink rubber eraser using a ballpoint pen. Then he bent and twisted the eraser, modeling stress and strain, until I finally got it! Afterwards, we spent the rest of the hour talking about his plans to encourage more women and minorities to study engineering, the state of the University of California's public funding gap, and how he was planning transformational changes in Berkeley's Academic Senate. It was the first of my many office visits to see Karl and learn from him.

Karl was a big supporter of the UC Berkeley Society of Women Engineers (SWE). During my senior year, I was elected the third President of the Berkeley chapter for 1976-77. In those years, only about 3\% of practicing engineers were women. SWE at Berkeley was just getting started, having been founded two years earlier. I asked Karl for advice on the best way to approach the Dean's office for funding, so that we could organize a barbeque at Strawberry Creek as our opening event. We were successful securing some budget money, and the event was well-attended with over 85 people. Much to our surprise, even Karl showed up! By the way, he also came for the first joint SWE and College of Engineering Informal Fondue Reception to welcome incoming transfer students. Only this time, he came along with College of Engineering Dean Ernest Kuh, associate and assistant deans, department chairs, and other faculty, so 20 professors and 60 students came.

Karl influenced my decision for SWE to focus on $7^{\text {th }}$ and $8^{\text {th }}$ grade girls for its first Outreach Program targeting that age group. He and I had talked during office hours about how young girls often were "tracked" into lower-level math classes early in elementary school and junior high, and then became discouraged about taking science classes in high school due to their inferior math skills. During April 1977, SWE sent out teams of SWE students and practicing engineers to give presentations at five junior high schools in Oakland and Berkeley. To stimulate the students' curiosity, we brought with us hands-on demonstrations, science experiments, films, and slides. We spoke to over 300 girls and encouraged them to consider engineering and science as possible career paths in college. When we won the National SWE Best Section Award that year, Karl celebrated with us.

After graduating with my B.S. degree in civil engineering, I was hired by Exxon to work at its California Benicia Refinery, first as an environmental project engineer, then process engineer, and finally as a refinery engineer and Energy and Oil Loss Coordinator (from 1977-1980). After three years with Exxon, I was ready to leave engineering to study for an MBA. But I didn't know much about business schools. Back to campus I went and conferred with my three favorite professors: Karl Pister, Alex Scordelis and Robert L. Wiegel. It was Karl who opened my eyes and suggested Stanford Graduate School of Business (GSB), a school I hadn't considered due to the long-time rivalry between Cal and Stanford. I had only thought about East Coast schools, but he convinced me that it was top-notch. In the end, I applied to 
HBS and Stanford, got into both, and happily chose Stanford. But I reassure the readers of this article: I do wear my Blue \& Gold to sports matches!

Still, being in the Bay Area had its advantages; it meant Karl and I could team up again, as he was now dean of the College of Engineering. In 1981-82, I shared with him my dream to organize the first Stanford Conference on Entrepreneurship with students from both the GSB and School of Engineering managing the event. Karl agreed to attend our all-day conference, which featured prominent Silicon Valley entrepreneurs, venture capitalists, panelists, and workshops. That day, Karl discussed with the deans of both Stanford's GSB and the Engineering School the ways he envisioned enhancing collaboration between Berkeley's College of Engineering and the Haas School of Business. His dialogue with the deans, and our highly successful student conference, were early catalysts to get a permanent Center for Entrepreneurship established at Stanford, and for joint courses to be offered by the Engineering School and the GSB many years later.

After I married my Swiss husband in 1984 and we moved to Europe, I quickly discovered that a California professional engineering registration was not recognized overseas, so I ceased practicing engineering. Shortly thereafter we were transferred by his company to Barcelona, Spain where I landed a job as an assistant professor at ESADE Business School, a leading private university in Spain.

From 1978-1981, Dean Ernest Kuh had asked me to serve on the Steering Fund Committee for the Berkeley Engineering Fund (BEF). From the BEF experience, I saw first-hand the challenges Berkeley faced in fundraising, which would prove useful in short order. Now that he was dean of the College of Engineering, Karl spearheaded the internationalization of the UC Berkeley Engineering Alumni Society and worked hard on fundraising. He was passionate about the need to support social, professional, and educational networking opportunities for students and alumni in a lifelong learning compact. Karl invited me to help him set up the Berkeley Engineering Alumni Society in Europe. Our first challenge was to find the alumni!

Marily A. Howekamp (BA '66) from the College of Engineering Development Office would help us. Marily had worked for the Cal Alumni Association before being hired by Dean Kuh in 1980 to lead a fundraising program for the College. Marily sent me lists with the names of prominent Berkeley engineering alumni, while I created our first database using Apple's Hypercard. I cold called the names and those who answered usually agreed to help call upon others. I personally visited alumni in Barcelona, Madrid, Zürich, and Geneva. Karl and I learned that not many engineering alumni lived in Spain and Switzerland, but Karl's biggest surprise was to learn that I had discovered a large nucleus of French alumni in Paris, who were very active as a chapter. They just hadn't told the dean what they were up to!

Finally, my last anecdote to share is that I turned to Karl when I needed someone to write the foreword for my book From Innovation to Cash Flows, a comprehensive guide for entrepreneurs. Karl and Henry Chesbrough, faculty director of the Garwood Center for Corporate Innovation at Haas School of Business, co-authored a wonderful foreword for the book, which became a best-selling Wiley textbook in Spain.

As you can see from these stories, Karl has been a life-long friend and supporter. He's had a huge influence on my life and I'm grateful for all the adventures we've shared. Even today, well into his 90's, Karl is spending his spare time learning Italian! So, in closing, Karl, auguri di buon compleanno!

Constance Lütolf-Carroll

Senior Lecturer of ESADE Business School, Ramon Llull University

Email: constance.lutolfcarroll@esade.edu

Book site: www.innovationtocashflows.com (Internet archived on 2021.06.06) 


\section{Celebrating the 95th birthday of Professor Karl S. Pister}

\section{Tribute by Professor Ekkehard Ramm}

It all began in September 1972 when I started my time as a visiting scholar in the SESM Division at UC Berkeley. After two weeks I entered the office of Janet McDonald on the $7^{\text {th }}$ floor of Davis Hall, the very kind and helpful secretary of the Division. A side door opened, and a friendly Professor appeared; the door sign indicated 'Chairman of Division'. "Who are you?"- "My name is Ekkehard Ramm, I am a Postdoc from the University of Stuttgart in Germany". He introduced himself and asked me into his office. He started speaking German and mentioned that his ancestors came from Germany. "When did you arrive?""Two weeks ago; I was asking for an appointment with my supervising professor". "You should have come earlier! You don't have to wait; you just go directly to the professor." What a difference to our academic system where we are used to saying, 'Herr Professor', and had to wait until the professor defines a date. From this discussion I recall his critical comments on the' publish or perish' system; he said every young scholar should get 20 tokens for publications the scientist can use in the entire academic career whenever it is appropriate. At that time, I did not really understand the meaning because I was raised in a different environment. Today I think it is even more important to stress quality instead of quantity. Finally, he said "If you need any help, please come again".

What a great beginning of a wonderful and successful time, for me and my family. I joined the research group of Ed Wilson and cooperated with Jürgen Bathe working on the theoretical and algorithmic basis for the code NONSAP. I benefited from the great resources of scientific reports and papers on continuum and structural mechanics of the famous Berkeley school. Later I learned that much of it goes back to what was known as the "Pister Research Machine", including Bob Taylor, Leonard Herrmann and Tom Hughes, among others. I primarily worked on geometrical nonlinear problems and compared what I called the Total and Updated Lagrangian formulation.

In June 1973 my wife Annette and I were invited by Professor Pister for dinner in his house in Lafayette. We experience the specific personal atmosphere and in particular the hospitality of Karl and his wife Rita. How often have I been there since that time! On this day we learned that the Pister family will come to Stuttgart for Karl's sabbatical at the Institut für Statik und Dynamik ${ }^{2}$ (ISD) of John H. Argyris. Thus, in October 1973 we met again and realized that the equipment of the apartment in the University guest house was not sufficient for the large Pister family. So, we could support them not only by advice but also by furniture. During the following months we often met, and a very close friendship developed. One day Edmondo Vitiello from Milano visited the Pisters, a previous visiting scholar of Karl we met already in Berkeley. The Pisters planned a tour through Germany and neighboring countries; Karl did not find a hitch of his car for a camping trailer in Stuttgart. I joined him for a successful trip to the city of Karlsruhe. These days we also often talked about the specific leadership in the ISD.

Karl returned to Stuttgart for a short time in 1975 and for nine months in 1978. He even took care of our house when we went skiing to Switzerland for two weeks at the end of March 1978. Later Rita joined

him again. A highlight was the FENOMECH 1978 Conference organized by ISD on the occasion of the $65^{\text {th }}$ birthday of J.H. Argyris at the end of August. I recall that Karl played the role of a toastmaster during the banquet in the Institute; he must have had a hard time organizing the many speeches honoring the Jubilarian; I remember that we had to leave at 11:30 at night before the dinner was served since our babysitter's time had ended.

\footnotetext{
${ }^{2}$ Institute for Statics and Dynanics.
} 
I skip my many visits to the Bay area in the sequel and would like to concentrate on important events and meetings with Karl. In 1989 I spent a six months sabbatical in Berkeley. Karl, being the Dean of Engineering, offered me his office in Davis Hall, a great help for me which allowed me to use his rich library and the internet for emails. I carefully studied the paper by Simo, Taylor and Pister on Variational and projection methods in finite deformation elasto-plasticity (CMAME 1985), related to the consistent linearization for the algorithmic tangent. A couple of years later Annette and I visited the Pisters in Santa Cruz in their huge house during Karl's time as chancellor of UCSC.

In 2001 some of my previous students organized a scientific meeting at Schloss Hofen close to the Austrian city Bregenz at the Lake of Constance on the occasion of my $60^{\text {th }}$ birthday. It was attended by many close friends from all over the world including Karl and Rita; it was a great honor for me that Karl gave a dinner speech at the banquet, what he called a spoken "Festschrift" (see IACM Expressions 11/01). He referred to my special relation to the Golden Gate Bridge and the many lectures I have given on the history of the bridge. It was a touching moment for me, in particular when he gave me a picture award from the construction of the bridge. Since I regularly visited the engineering team of the Bridge District in charge of the seismic retrofitting project, I asked Karl to join me for an excursion to the site. It was a great experience for both of us; I was impressed by his detailed knowledge as a witness during the lifetime of the bridge.

I also would like to mention NAE annual meetings in Washington DC, when Karl used to invite some colleagues for dinner, among them Bob Taylor and Kaspar Willam. In 2010 we met in a kind of official function during a meeting at UC Berkeley. I was a member of a subcommittee of the German Council of Science and Humanities making a field trip to the US learning about the "Structure and Governance in U.S. Higher Education". The group had a discussion with the Director of the Center for Studies in Higher Education Jud King and its Predecessor Karl Pister. What a coincidence! Two years later Karl invited me for an excursion to his mountain cabin in the Sierra Nevada, a fascinating experience at the altitude of 7800 feet. Organized by Kaspar Willam, we could celebrate Karl's $90^{\text {th }}$ birthday together with some colleagues in San Diego during the USNCCM in 2015.

I never cooperated with Karl Pister in the sense of a direct scientific interaction; however, I benefitted indirectly from his outstanding influence on the Berkeley school. Nevertheless, for me he is one of the most valuable persons I have met in my life. Our friendship started a long time ago and has grown and enriched our lives with wonderful experiences and memories. I always had the impression that Professor Karl Pister is mostly working for a better society and for other people, instead of concentrating on his own interests.

Dear Karl, I am so grateful for your friendship and for all you have done for me. My best wishes may accompany you in the years to come.

\section{Dr. Ekkehard Ramm}

Professor Emeritus Dr.-Ing.

Universität Stuttgart

Institut für Baustatik und Baudynamik

Institute of Structural Mechanics

ramm@ibb.uni-stuttgart.de

Web page: https://www.ibb.uni-stuttgart.de/en/institute/team/Ramm/ (Internet archived on 2021.06.27)

Editor's note: See the Supplements section where there are photos related to the events mentioned above by Professor Ramm, including the FENOMECH 1978 conference and the 65th birthday celebration of the late Professor John Argyris. LVQ 


\section{Celebrating the 95th birthday of Professor Karl S. Pister \\ Tribute by Dr. Paula Hawthorn and Dr. Barbara Simons \\ Former President of the Association for Computing Machinery (ACM)}

Several of us worked for three years to get the innovative Reentry Program established in the College of Engineering. This was not your usual "give extra money \& support to minority students." Instead, it had a far more ambitious goal, namely making it possible for underrepresented groups, especially but not exclusively women, to earn advanced degrees from major universities - ideally Ph.D.s - in computer science.

The program would be targeted at women and other minorities who had undergraduate degrees in nonengineering areas, who desired to apply for graduate school in the College of Engineering but did not have the required prerequisites, and who were vetted $\&$ accepted by an acceptance committee. These students would be a part of a two year program that would facilitate their taking undergraduate courses, after which they would apply to graduate school based on their records in those classes. It was important that the classes be regular, not remedial, and that the program be fully integrated within the College of Engineering, except that the students would be admitted as "special students".

The unique proposal ran into a lot of opposition because the faculty had never before seen anything similar. Barbara and Paula spent many hours in faculty offices lobbying for the program, while Dr. Sheila Humphreys (whose tribute to Professor Pister in this issue contains more details on the effort) wrote grant requests and lined up potential industrial sponsors.

BUT, when Karl Pister became Dean of Engineering, everything changed! We did not have to argue with him, convince him, cajole him: Dean Pister was an advocate for the program immediately. He became our ally and our friend and was key to getting this program and many others started.

Dean Pister's commitment to diversity was genuine and highly unusual at the time. It was a joy to work with him, and we remain grateful for his timely and unwavering support.

Thank you, Dean Pister.

Dr. Paula Hawthorn paula.hawthorn@gmail.com
Dr. Barbara Simons

Board Chair, Verified Voting

https://verifiedvoting.org/ (Internet archived 2021.07.20)

Board of Directors (Internet archived 2021.07.20),

including a short biography.

barbara.b.simons@gmail.com 


\section{Celebrating the 95th birthday of Professor Karl S. Pister}

\section{Tribute by Cooper-Union Vice President Antoinette Torres}

You ask about my memories of Karl Pister. Maybe a recollection of a time way back, when Karl Pister undertook to steward a model of educational excellence founded on the strengths and ability of a diverse STEM enterprise. When he envisioned pathways for traditionally under-represented populations to not only engage in the top ranked engineering education that UC Berkeley offered, but to become part of it. He advanced true equity - a paradigmatic shift in which diverse viewpoints, experiences, perspectives and approaches had a place in hallowed halls. And maybe a memory of how Karl entrusted us to engage in his ambitions to expand the reach of Berkeley to engage new kinds of talent and greater excellence.

Rather though ask me about how I was changed; and how the course of my life took form because of the confidence Karl provided me, often in those one-on-one's in his office. To which you greeted me with the same kind interest and attentiveness that Karl provided me. His value for empathy, respect and understanding began at that threshold. I learned in those moments of engagement with Karl —and problem solving and ideation - that good ideals and goodness of purpose could co-exist in engineering education. That the great challenges in engineering were also societal and human challenges. Strangely, in joining with the College of Engineering (1980's ish) a more complete experience of UC Berkeley took form for me. From being a proving ground where my academic and intellectual abilities were challenged to, in Karl's office, belonging. I was heard and valued; and engaged in a purpose that is with me today. I came to understand Karl as a leader with ideals and integrity; and as a stalwart guardian for right being. This is the kind of leader / steward I aspire to become. I say "become" because it is a life's work.

Funny, my memories of those moments with Karl in his office are always sunny. His office in my remembrances seem always to be filled with light. This is my memory of Karl Pister - a joy in the moment; in the person. As burdened as he was, by the enormity of whatever he was about, by the work of the day and demands of so many constituents, Karl was authentically, earnestly and joyfully present. His was the light.

Ms. Antoinette Torres

Vice President, Strategic Initiatives and Institutional Effectiveness

The Cooper Union for the Advancement of Science and Art

toni.torres@cooper.edu

Cooper Union President's Office (Internet archived on 2021.06.28) 


\title{
Celebrating the 95th birthday of Professor Karl S. Pister
}

\author{
Tribute by Professor Carlos Felippa
}

\author{
Remembrances of Berkeley in the Mid-Sixties
}

\section{Two Worlds Apart}

When I entered the University of California at Berkeley (UCB) in Fall 1963 to do graduate studies in Civil Engineering (CE) at SESM (Structural Engineering and Structural Mechanics Division) my knowledge of mathematics and mechanics could be rated as "adequate" but certainly not outstanding. It was tailored to be an Ingeniero Civil (IC) in my native country: Argentina, at the Facultad de Ingenieria of the Universidad de Cordoba. The IC curriculum had been established in the late XIX Century by German professors hired by the Argentine government. The six-year curriculum was very rigid: no electives and only one final degree, which was necessary and sufficient to exercise the profession. IC graduates typically joined small construction or consulting companies, started their own, or went to work for government agencies. Most faculty were part time. The content of many courses, especially in physics and mathematics, had remained stationary for decades. The computational tools were portable slide rules and office desk calculators.

Graduate studies at UCB were a different story. Not less since the CE department had been rated then, and for long afterwards, the top one in the world. The full department was actually huge: over 100 faculty, comprising four Divisions: Hydraulics and Naval, Soils, Structures, and Transportation. Each Division had its own building. Why so big? It was the post-Sputnik era: plenty of funding for engineering and sciences. And California was booming. My first (Master) year was spent as a Research Assistant under Vitelmo "Vic" Bertero. He was an MIT-graduate exiled Argentinian (actually a distant relative of my father), who by the early 1960s had become one of the top US experimentalists in reinforced concrete. He had convinced me to choose UCB for graduate work. But upon finishing the Master in two semesters I realized that I had no appetite or aptitude for experimental work: lacked the necessary dedication and patience.

Luckily Ray Clough had returned in summer 1964 from a year sabbatical at Trondheim (Norway) and was looking for a doctoral student to continue research work in the then young (10-year-old) Finite Element Method (FEM), a name he had coined in 1960. Vic recommended me, telling Ray that I was proficient with computers, a tool I had discovered in my second semester while taking a Fortran II course. So I became the \#4 UCB student doing a FEM thesis, following Ari Adini, Ed Wilson and Jim Tocher. ${ }^{3}$

For FEM doctoral work four topics had to be mastered: advanced applied mechanics, variational methods, computational linear algebra, and basic numerical analysis. Computer science is left out since in the early 1960s that was yet not a formal academic discipline. (The first Computer Science department was set up by George Forsythe at Stanford in 1965 --- the name was his idea.) PhD-level programming was learnt by osmosis from young faculty (in SESM: Ed Wilson and Bob Taylor) or experienced doctoral students.

\section{Karl Pister's Courses}

Karl Pister, then 38 but already a rising star in Applied Mechanics, was strongly influential in my mastering the first two topics. Two of his courses I still remember: Advanced Mechanics of Materials (CE 230A, Fall

\footnotetext{
${ }^{3}$ Editor's note: See the recollection of Professors Clough and Wilson on the early developments of the FEM in the Supplements section in conjunction with the photo of the FENOMECH 1978 banquet honoring the 65th birthday of the late Professor John Argyris. LVQ
} 
1963) and Theory of Plates (CE 232, Spring 1964). Kept the handwritten notes (taken shorthand in class, then transcribed and cleaned up at home). The first 230A lecture, given on 18 September 1963, introduced Cartesian tensors for "analysis of deformation and motion". From those lecture notes I quote an example he nonchalantly wrote on the blackboard: $\delta_{i i}=3$, and asked the students to explain. Having never encountered a tensor (of a matrix) before, I was completely lost. Fortunately I was able to catch up after a few weeks.

A brief historical digression on teaching Structures is appropriate here. Structural theory was largely developed during the period 1820-1870 in Europe (primarily in France, Germany, Italy and the UK) as prompted by the rapid growth of metal construction during the Industrial Revolution. It focused on linear elastostatics models, with ad-hoc extensions to cover stability, dynamics, flow and fracture phenomena. A companion, physically oriented instruction style, was popularized in the 1930s beyond Europe by Stephen Timoshenko through 12 textbooks translated to 35 languages. The underlying mathematics would be familiar to Euler but was sufficient for most applications. But a more rigorous competitive style, somewhat hyperbolically labeled "rational mechanics," emerged over the post-WWII period (primarily 1952-1965) blending axiomatics, continuum mechanics, nonlinear constitutive models, tensor analysis and history functionals.

This "new wave" barely impacted most CE departments before 1980 since its forte was modeling emerging materials such as polymers and piezoelectrics, which were uncommon in that branch of engineering. To his credit Karl Pister incorporated this style in his courses since coming to UCB: gently at the master level (e.g., keeping tensors Cartesian) and more fully in doctoral courses. ${ }^{4}$ The introduction of fundamental assumptions, such as the principles of heredity, locality and equipresence, is characteristic of the rational mechanics framework.

The full title of CE232 was "Two Dimensional Problems in Mechanics of Linear Solids with Applications to Plates." The course references listed books by Sokolnikoff, Muskhelishvili, Timoshenko, Novozhilov, Girkmann, Eringen, Boley \& Wiener, Green \& Zerna and Milne-Thompson. An eclectic blend of old and new. Part I: Problem Formulation, dealt with classical topics in linear elasticity. More interesting to me was Part II: Solution Methods, which spanned Complex Variable Methods (a Russian favorite), Integral Transform Methods (popular in Europe), Method of Singularities (a synonym for Green's functions, which when combined with FEM discretization ideas eventually spawned the Boundary Element Method) and Approximate Methods. The latter covered Variational Theorems (meaning Rayleigh-Ritz and Galerkin techniques) and Direct Numerical Methods.

FEM was given a short shrift in the latter: provides answers but not solutions. The quick demise was understandable at the time. By 1964 FEM (often called Matrix Methods at the time) was exploding in the then booming Aerospace industry, which had plenty of funding to purchase and operate computer mainframes that cost the equivalent of $\$ 50-100 \mathrm{M}$ in today's dollars, and required a dedicated supporting staff. On the other side, Civil Engineering companies were usually small and lacked such resources; sticking with desk calculators until inexpensive PCs appeared in the early 1980s. And FEM cannot exist without computers.

That explains why only a few faculties at the time were aware of the digital revolution. Indeed most SESM faculty who joined before 1960 were not computer savvy. Ray Clough was an exception since he participated in the creation of FEM, along with Jon Turner and Harold Martin, during Visiting Junior Faculty stints at Boeing in the summers of 1952-53. (It helped that he had received an Aero-Astro PhD at

\footnotetext{
${ }^{4}$ Editor's note: Included in the Memory-lane section are Prof. Felippa's CE230A handwritten class notes, in which Prof. Pister's coverage of constitutive equations beginning on 18 October 1963 can be found. LVQ
} 
MIT, where he learned matrix methods, already popular in aeroelasticity, from Bisplinghoff.) SESM junior faculty hired in the early 1960s, such as Ed Wilson and Bob Taylor, quickly adapted to the incoming world. ${ }^{5}$

\section{Postscript: Draining the Variational Swamp}

Variational methods (VM) are FEM bread and butter. On arriving at UCB my knowledge of the subject was limited: just the Euler-Lagrange equations and some classical problems solved by Leibniz, Newton and the Bernoullis centuries ago. Courses by Karl Pister, Egor Popov, Joe Penzien and Alex Scordelis introduced me to Rayleigh-Ritz and Galerkin approximants in full generality. In 1962 Bob Melosh (a Boeing employee at the time), had established the connection of conforming FEM to Rayleigh-Ritz in his Washington University thesis under Harold Martin. So I was able to put two and two together for my doctoral work. In 1966 I was able to extend VM in FEM to model geometric nonlinearities (after reading Biot's book) and material nonlinearities (Levy-Mises-Reuss plasticity, after reading Hill's book). Overcame the final challenge: inelastic post-buckling, which combined those two nonlinear models in FEM for the first time, and the thesis was done. Defended December 1966.

My interest in VM continued during my postdoc at UCB (1967, the San Francisco "summer of love" year) but then I joined the aerospace industry. First the Boeing Company Commercial Division (1968-1970) at Renton and then Lockheed Missiles and Space Company (1971-1986) at Palo Alto. Theory had to take a back seat to software development and Cold War projects but I kept vaguely aware of ongoing FEM work. After joining the University of Colorado at Boulder in 1986 as full professor I was able to pay more attention to what was going on. The FEM world had changed.

During 1965-85 FEM had been liberated from the Rayleigh-Ritz yoke. Clever but fragmented developments had produced hybrid-stress, assumed-strain, nonconforming, reduced and selective integration, and free-formulation elements, with a dizzying gallery of variants and combinations. Associated variational principles were all over the place, forming what might be dubbed a "variational swamp," difficult to visualize and traverse. Much of my research work over the period 1987-1994 was devoted to draining the swamp. The long march had a happy ending with the discovery of templates, a topic briefly outlined in the paper contributed to this issue.

Happy Birthday Karl, and thanks for the memories of younger times!

Dr. Carlos A. Felippa, Professor

Department of Aerospace Engineering Sciences and Aerospace Mechanics Research Center

University of Colorado

e-mail: carlos.felippa@colorado.edu

\footnotetext{
${ }^{5}$ Editor's note: See also R.W. Clough and E.L. Wilson, Early Finite Element Research at Berkeley, Fifth U.S. National Conference on Computational Mechanics, Aug. 4-6, 1999, (Internet archived on 2020.10.27), which is mentioned in the Supplements section in connection to a photo at the FENOMECH 1978 conference, and in the Biographical time line section. LVQ
} 


\title{
Celebrating the 95th birthday of Professor Karl S. Pister
}

\author{
Tribute by Mr. Brant Smith
}

Karl Pister and I first met on a hot, sunny day in his new office in the late summer of 1991, not long after he was appointed as interim Chancellor of UC Santa Cruz. I was the elected Student Union Assembly Chair (a position analogous to Undergraduate Student Body President at less idiosyncratic universities) and it was my job to be the main undergraduate liaison to the Chancellor. I knew nothing about him except his prior leadership at UC Berkeley's College of Engineering, which was a dangerous indicator for a long-haired Santa Cruz radical such as myself at the time. In fact, he had been warned about me, since it was believed that one of my platform planks I ran on during the election was that I got rid of the previous Chancellor. (That's not $100 \%$ accurate, but I don't think the previous guy was sorry to see me in the rearview mirror.)

Chancellor Pister had every reason to mistrust and avoid me -- campus activists and campus administrators typically being congenital adversaries. Instead, he welcomed me in (and the other student leaders) and quickly disarmed us with his honesty and humanity.

He said he identified somewhat with Santa Cruz's legacy of protest, confiding early on that he had nearly been "at the barricades" himself as a young professor at UC Berkeley during the tumult of the 1960's. In our first meeting, he also spoke about the wonder and awe of coming to work each day amongst the "cathedral of redwoods."

This is not how UC administrators usually speak.

We wrestled with many contentious issues during his tenure, including budget cuts, campus development and diversity, among others. But through-out, we maintained a strong, respectful and genuinely affectionate relationship. Chancellor Pister deserves most of the credit for this, since probably the kindest thing most UC administrators would say about me at the time was that I was tenacious (other things they might say are unprintable in a scholarly journal such as this).

One of the honors of serving as UCSC SUA Chair is the once-a-year meeting with the UC President (along with the other UC student body presidents). That was later in that first year and I made a point to tell UC President David Gardner to make Interim Chancellor Pister our permanent Chancellor at UCSC. I think he just about fell over. He couldn't believe the Santa Cruz student activist was advocating to keep someone in the big chair this time.

But that's testimony to Chancellor Pister's wise and kind leadership. He brought in smart people to work on the environmental planning for the campus - a welcome change from years of poor planning immediately before that. He made his legacy fundamentally about diversity and access for underrepresented communities, especially from California's community colleges. This wasn't typical administrative lip service. And he helped steer the campus right during budget cuts and challenging times (one illustrative example: he cut funding for the head of Public Relation's secretary, which is as strong a bureaucratic statement as one can imagine about the importance of truth and transparency). 
While his impact and leadership on the Big Issues of the day are irrefutable, his impact on me is much more personal. As I've grown to (shall we call it) middle age, it's clear that Chancellor Pister has had one of the most profound impacts on my concept of leadership and, more importantly, on my idea of collaboration. He is a kind person and genuine, his judgement relying on a fair and humane common sense. I know I fall way short of his measure on all these points, but his example has been a life-long inspiration and aspiration.

My experience is solely with him as a leader and a friend, so I know almost nothing about his academic work and research. But I do know this about his engineering skills: the structures, materials and buttresses that he helped forge within me through his example of daily integrity and humanity - that carry forward into the interactions I have with others and then so on from them - I expect will outlast us both.

Mr. Brant Smith

Senior Engineering Program Manager, Software Engineering

Apple Inc.

branticus@gmail.com

www.apple.com 


\title{
Celebrating the 95th birthday of Professor Karl S. Pister
}

\author{
Tribute by Professor Peter M. Pinsky
}

\section{Dear Karl,}

Congratulations on your birthday. I'm so pleased to be able to share a few reflections from my time as your $\mathrm{Ph} . \mathrm{D}$. advisee. I arrived at UC Berkeley as a doctoral student in 1976 after working for some years as a consulting structural engineer in Australia and Canada. I had decided that I wanted to make a change in direction and try my hand at research in the areas of mechanics and the finite element method. In my application I had requested to work under the supervision of Professor Robert L. Taylor. However, it was eventually proposed that you would be my co-advisor and that proved to be an excellent arrangement.

I well recall attending your introductory course in solid mechanics in my first quarter. In this course you reviewed some of the main topics in continuum mechanics and introduced the framework of consistent linearization, a theme beautifully expounded in your follow-up courses. I found the material exciting, powerful and full of potential -- in both senses of the word. But it was not simply the technical content of your courses that was impressive -- your friendly manner and approachability were hallmarks of all the courses you taught. You welcomed me and other students into your office hours with a particular kind of openness and willingness to engage in discussion that was so satisfying. I always looked forward to attending your classes, many of which started with your personal observations about life and events that revealed your wisdom about the world beyond mechanics.

As my advisor, you promoted my training in ways that stimulated and occasionally even shocked me. For example, you announced without much discussion that I would teach a course on advanced topics in computational mechanics. Suddenly, I was preparing lectures to present to a group of doctoral students and some faculty and feeling a little queasy about how I would manage to do it. But it was a great experience for me - perhaps less so for the attendees. I also fondly recall our regular visits with Bob Taylor to the Lawrence Livermore National Laboratory for discussions about our ongoing research. Your knowledge of mechanics and skill in presentation opened up new ideas and interesting directions while your interactions with Bob Taylor were invigorating and showed the power of collegial collaboration.

Your accomplishments in the realm of teaching and research were to be a prelude to your leadership role as Dean of Engineering at UC Berkeley, Chancellor of UC Santa Cruz (my stepson is a proud Slug) and in many other capacities. Through your various roles you have contributed in many important ways to the betterment of society. On this most auspicious occasion of your 95 th birthday I would like to thank you for all that you have done, not just for me, but for the broader community.

Last but not least, I wish you a very happy birthday -- Peter Pinsky.

Dr. Peter M Pinsky

Professor Emeritus of Mechanical Engineering

Stanford University

pinsky@stanford.edu

https://profiles.stanford.edu/peter-pinsky (Internet archived on 2021.06.28) 


\section{Celebrating the 95th birthday of Professor Karl S. Pister}

\section{Tribute by University-of-California-at-Davis Chancellor Gary May}

Karl, congratulations and best wishes to you on your 95th birthday! For this very special occasion, I wanted to share a few reflections about your impact on my life and the lives of so many others.

After graduating from Georgia Institute of Technology in 1985 with a B.E.E. in electrical engineering, I arrived at UC Berkeley to work on my M.S. (1987) and Ph.D. (1991), both in electrical engineering and computer science. Karl was dean of engineering at this time, and I was also lucky enough to be a grad school classmate of Karl's son, Kris, who is now on the faculty at Berkeley.

Karl's influence, particularly in advocacy and support for teaching and promoting diversity and inclusion in higher education, was among my inspirations when I went on to become dean of engineering at Georgia Tech. There, I founded the Summer Undergraduate Research in Engineering/Science (SURE) program, designed to attract talented minority students into graduate school. I also founded and directed Facilitating Academic Careers in Engineering and Science program (FACES), a program designed to encourage minority engagement in engineering and science careers in academia. Karl's support and encouragement were never more than a phone call or email away.

Karl has always been a supporter of others, encouraging our efforts and sharing our achievements with his trademark wisdom and humility. I was honored to learn that he was a reference for me for my NAE election in 2018. Not only did he care about us while we were his students, he continued to mentor and advocate for us all as we moved ahead into our own careers.

Last year, when Karl learned that Darryl Pines, who had participated in the MEP program at Berkeley, had been chosen as the new President of the University of Maryland, he contacted me to find out if I had heard the good news and knew Darryl's email address. He was excited to reach out to him, and shared with me how proud he was of all of his MEP graduates. I was deeply touched and, as always, inspired by the way Karl supports and celebrates all of the people whose lives he has impacted.

Karl, thank you. You are not just a legend in engineering and education - you have been and will always be an inspiration, a role model, a mentor and a friend to me and so many others. We proudly stand as your legacy and as a testament to your commitment, your wisdom, your compassion and your vision.

Happy Birthday!

Dr. Gary S. May

Chancellor of the University of California at Davis (Internet archived on 2021.05.27)

chancellor@ucdavis.edu

Wikipedia: 'Gary S. May' (Version 14:36, 8 July 2021) 


\title{
Celebrating the 95th birthday of Professor Karl S. Pister
}

\author{
Karl S. Pister and the Foundation of Diversity in Engineering \\ By Dr. Sheila Humphreys \\ With contribution and editing by Professor Loc Vu-Quoc
}

\begin{abstract}
"When I was dean, I took diversity as a high priority and invested a lot of resources to help students make that adjustment and increase the underrepresentation of women and ethnic minorities." -Karl S. Pister
\end{abstract}

Dean Karl S. Pister's exceptional commitment to diversity in the College of Engineering built the strong foundation on which the College's diversity program still stands. Pister came first to Berkeley as an undergraduate in 1941 in civil engineering. His increasingly senior positions at the University of California included professor in the Department of Civil and Environmental Engineering (1952-1996) at UC Berkeley, chair of the systemwide Academic Senate in 1979, chair of the systemwide Academic Council from 1979 to 1980, chair of the Berkeley campus Educational Policy Committee, and chair of the university-wide Committee on Educational Policy. When chair of the systemwide Academic Council, Pister commissioned a comprehensive report on faculty involvement in student affirmative action that was delivered to systemwide President David Saxon. ${ }^{6}$ (Inset photo credit Peg Skorpinski.)

Thus, when Pister became dean of the College of Engineering in 1980 (subsequently serving until 1990), he arrived on the job with deep expertise and knowledge of the relevant challenges. "People are the new 'gold' to be mined in California," he said. He was mindful of the pledge

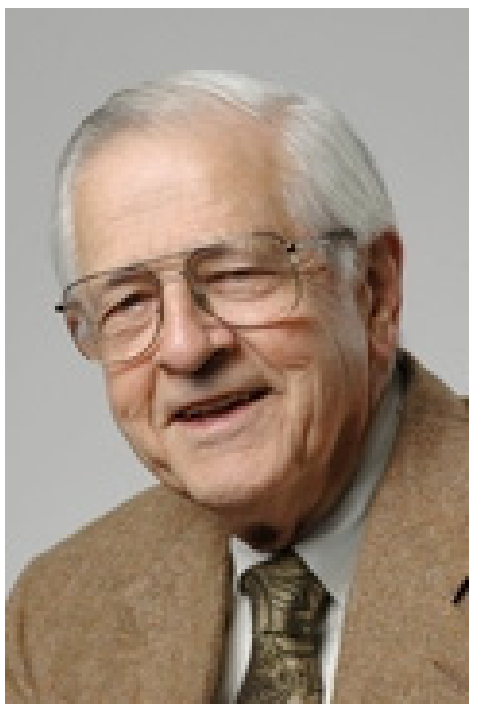

Dean Karl S. Pister of President Daniel Coit Gilman at his inauguration in 1872: "The University of California ... is the University of this State. It must be adapted to its people, to their public and private schools, to their peculiar geographical position, to the requirements of their new society and their undeveloped resources." Likening students from underrepresented backgrounds at the university to California's new gold, Pister urgently declared the need for "a full-scale effort to develop the vastly underutilized pool of human resources that reside in the people of our state."

\section{Report of the Universitywide Task Force on Faculty Rewards}

\section{June 26, 1991}

Karl. S. Pister, Report of the Universitywide Task Force on Faculty Rewards, University of California, Office of the President, June 26, 1991. Internet archived on 2019.04.26.

\footnotetext{
${ }^{6}$ Vivian Auslander, "Faculty Involvement in Student Affirmative Action: Report to the Chair of the Academic Council" (University of California, April 10, 1980).
} 
Dean Pister championed student diversity at all levels, from pre-college to postdoctoral students. From the outset, he recognized the need to develop and fund specific programs for both undergraduate and graduate students: "I began to realize the difficult cultural adjustments students from disadvantaged backgrounds and women face coming to the University, particularly into certain disciplines. When I was dean I took diversity as a high priority and invested a lot of resources to help students make that adjustment and increase the underrepresentation of women and ethnic minorities. We made significant strides during my tenure - the number of women in the engineering program doubled and significant progress was made to bring in more underrepresented minorities." 7

Pister also understood that most faculty members require incentives in order to prioritize their limited time to advance diversity. He chaired the University of California's Universitywide Task Force on Faculty Rewards, dedicated to officially changing the faculty reward and promotion system, which included a strong recommendation to recognize faculty contributions to affirmative action. The Task Force report, delivered in 1991, contains this recommendation: "The development of human resources through personal mentoring and active involvement in affirmative action and other equity- and diversity-oriented pursuits is integral to the life and purpose of the University. ... As the population of the state becomes more diverse, the populations of students and faculty must also become more diverse. Implementation of these and other diversity goals is a shared responsibility among all faculty, and faculty should be encouraged to pursue these activities and be rewarded for meritorious achievement in the areas of equity and members." 8 The Task Force's recommendations eventually were adopted across the university, and yet the role of diversity contributions to academic promotions remains an issue. The recommendation was way ahead of its time, and only now, thirty years later, has this policy been adopted and even required for faculty applicants.

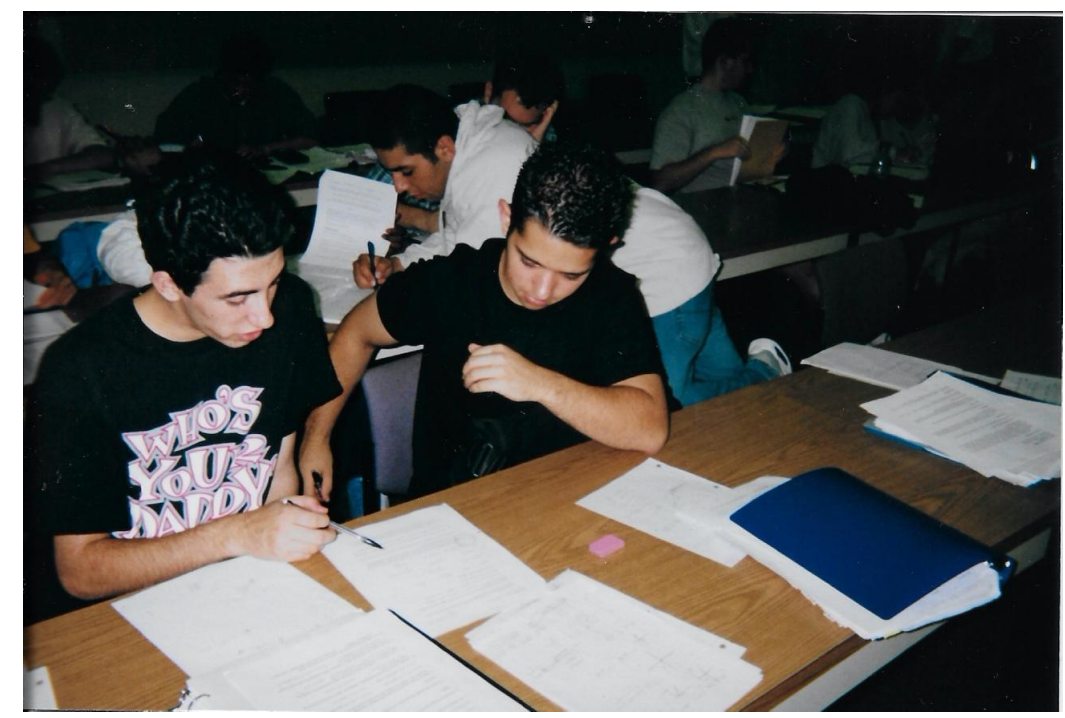

Scott Moura and Franklin Dollar, Minority Engineering Program (MEP) participants, circa 2000. Both are now professors.

At a universitywide affirmative action retreat in May 1987, Dean Pister reviewed the College's affirmative action program during his tenure as dean. He explained the College of Engineering's pipeline

\footnotetext{
${ }^{7}$ Karl S. Pister, "Whose University? The Rocky Road to Equity and Equality” (speech given at inauguration of Chancellor Robert Birgeneau, University of California, Berkeley, September 2008).

${ }^{8}$ Karl. S. Pister, Report of the Universitywide Task Force on Faculty Rewards, University of California, Office of the President, June 26, 1991. Internet archived on 2019.04.26.
} 
program, which encompassed pre-college through graduate students. The concept of a pipeline was relatively novel at this time. Pister contended that "an effective graduate affirmative action program can only be successfully built if it is attached to the end of a successful undergraduate program, which in turn is attached to successful pre-college, i.e., high school and junior high programs." ${ }^{9}$ Building a lasting framework for underrepresented students at Berkeley is exactly what Karl Pister accomplished through his leadership as dean.

\section{Minority Engineering Program (MEP)}

In pursuit of the goal of building an effective pipeline, one of Dean Pister's first actions when he became dean was to establish, in 1981, a support system for undergraduate students from diverse backgrounds. Dean Pister applied to the National Action Council for Minorities in Engineering (NACME) for a grant of $\$ 25,000$ to establish the program, called the Minority Engineering Support Program (MESP). As Pister relates in his oral history, "At Berkeley, Engineering was a leader in developing an undergraduate extension of MESA [Mathematics, Engineering, Science Achievement] in the 1980s. . . The Minority Engineering Program was instrumental in increasing minority graduation rates in Engineering. ... That program was designed to attract and retain underrepresented students in engineering at Berkeley. Later on that program was renamed the Minority Engineering Program (MEP) to make it congruent with a statewide effort that was connected to the MESA program. MESA had been focused on high school preparation for college and what we needed to do was to create a program that was focused on undergraduates initially."10

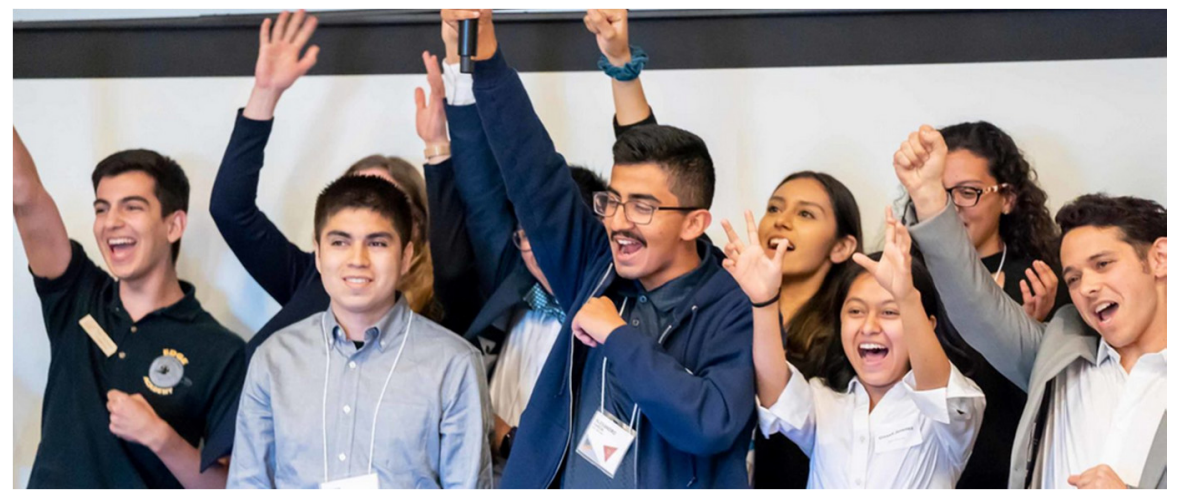

Boot Camp: The legendary MEP Pre-Engineering Program ( $\underline{\text { PREP }) ~ s u m m e r ~ o r i e n t a t i o n . ~ C r e d i t: ~ B e r k e l e y ~ E n g i n e e r i n g . ~}$

The dean allocated resources for staff positions to the MEP, which served underrepresented undergraduates in all engineering departments in the College of Engineering. Pister identified the multiple essential components for a successful minority support program: recruitment, admissions, financial and housing assistance, orientation, advising, academic support and tutoring, student study center, student organizations, personal counseling, and summer job assistance. These program elements remain in place today. The College's undergraduate admissions policy was purposefully revised to incorporate an emphasis on broader elements affecting a student's record, such as quality of high school and family background. Personal interviews of prospective students by MEP staff counted in decisions.

\footnotetext{
${ }^{9}$ Karl Pister, "Remarks Made at UC Systemwide Retreat on Graduate Student Affirmative Action" (Asilomar, California, May 20, 1987).

${ }^{10}$ Karl S. Pister, Oral History, Regional Oral History Office, the Bancroft Library, UC Berkeley, 2003, 255-257. Internet archived on 2021.03.09.
} 
MEP concentrated on recruiting a diverse pool of undergraduates and then bringing students of color into a structure of support rather than leaving them to fend for themselves. The emphasis of MEP during the 1980s was on retaining engineering undergraduates through graduation. Gradually, the MEP program evolved to encompass a new element: encouraging undergraduates to prepare for graduate school. By the end of the decade, graduate school became a goal for many MEP students.

The legendary MEP Pre-Engineering Program (PREP) summer orientation, called Boot Camp, brought incoming freshmen to campus to spend two weeks living in a dorm and taking classes before their first semester. Staff moved into the dorms with MEP students. New students took placement tests and brushed up on their academic skills in calculus, chemistry, and physics classes taught by graduate students. Future engineering professors like Gary May (PhD EE, 1991), Reginald Desroches (PhD CE, 1994), John Harkless (PhD chemistry, 2001), and Erika Whitney (PhD bioengineering, 2001) all taught Boot Camp classes. Both May and Desroches rose to become deans of engineering, at Georgia Institute of Technology and Rice University, respectively. Contact with upperclassmen through Boot Camp fostered influential friendships and peer mentoring across class levels. The freshman Boot Camp has continued for thirty-five years and now runs concurrently with a parallel program for transfer students. ${ }^{11}$

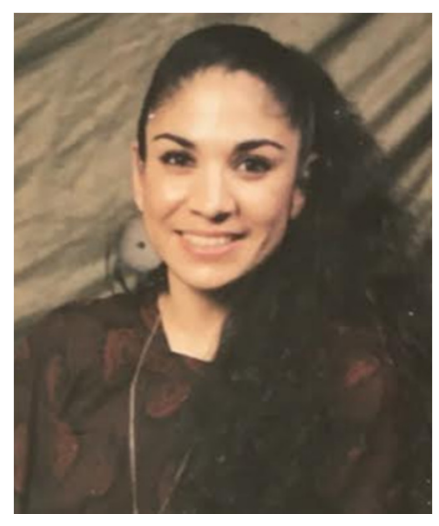

Ms. Antoinette "Toni" Torres
Ms. Antoinette "Toni” Torres led the MEP from 1987 to 1994. Deeply committed to the welfare of students, Toni Torres was a key figure in building the academic support infrastructure for MEP. ${ }^{12}$ Torres speaks of the inspiration she gained from her partnership with the dean: "He was unwavering in his conviction that diversity was integral to excellence in engineering. ... He was resolute in his belief that the great challenges in STEM would benefit from the voice, experience and insight of the broadest set of contributors, and that best practice would emerge from their collaborations." Torres calls the MEP model a "game changer-a model in which diverse students in the College of Engineering were acknowledged as bringing intellectual and interpersonal strengths to the academic enterprise." She attributes Pister's ambitions for the MEP to his "deep regard for human capacity and potential." 13

Early on, Torres realized that minority freshmen were underperforming in calculus and physics and were migrating out of engineering to other departments after their first year. To improve persistence, she developed what she called "highly customized advising" and created new academic programs to improve academic support. Torres collaborated with the campus Professional Development Program (PDP) to strengthen MEP student academic performance in math by directing all students to join the famous PDP Math Workshop Program, which fostered collaborative learning communities, resulting in higher grade point averages in math and improved retention to graduation. ${ }^{14}$

\footnotetext{
${ }^{11}$ For more information, see PREP website, Internet archived on 2021.01.26. Since 2015, transfer students have been included in a Boot Camp called Transfer PREP (TPREP).

12 Alumnus Dr. Kamau Bobb reports that Toni Torres personally provided lodging for him during the summer before he enrolled when his housing fell through.

13 Antoinette Torres, personal communication, May 2019.

${ }^{14}$ Rose Asera, Calculus and Community: A History of the Emerging Scholars Program (New York: College Board, May 2001), p.18. The Professional Development Program is described in detail in Asera's article. Outcomes of Treisman's Math Workshop model have been well documented, in his own PhD thesis (1985) and in Robert E. Fullilove, "Sealing the Leaks in the Pipeline: Improving the Performance and Persistence of Minority Students in College" (unpublished paper, University of California, Berkeley, 1986), p.9 and a few pages after that.
} 
Dr. Kamau Bobb, MEP participant in the 1980s, notes that the MEP brought students into "an entire infrastructure" of support. During Boot Camp, freshmen met students in student organizations like the Black Engineering Science Students Association (BESSA) and Black Graduate Engineering and Science Students (BGESS), with ties to the National Society of Black Engineers (NSBE). The College dedicated a physical space called the Academic Center where MEP students could gather, which turned out to be a very essential component of the MEP. The Center was "a place for students of color to feel bolstered if necessary or at ease in a protected space. All that sense of isolation, that just didn't apply," Bobb remembers. ${ }^{15}$ It is interesting that the overall Berkeley campus has recognized the symbolic and actual importance of dedicated space for underrepresented students, with the establishment in 2017 of the Fannie Lou Hamer Black Student Resources Center. ${ }^{16}$

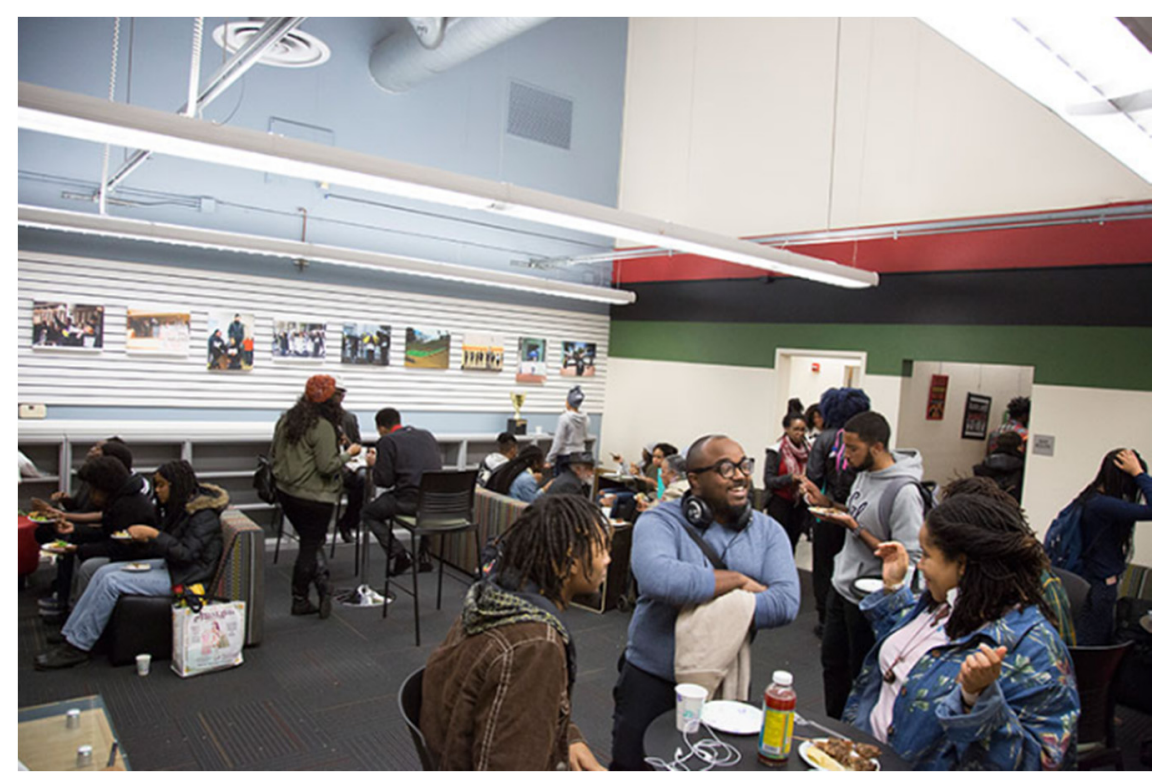

Fannie Lou Hamer Black Student Resources Center. Credit: Berkeley Engineering.

Milton Howard (BS, EE 1986) was an electrical engineering undergraduate in the first cohort of MEP students. He had connected with Berkeley through MESA as an Oakland high school student. The MEP group gave him the sense "that we were all in this together." The students formed instant study groups. Howard recalls how motivating Toni Torres was during his first two years and credits Charles Tunstall, the second MEP Director before Toni Torres, for his leadership of the group when Howard was an upperclassman as "one of the main reasons we went to grad school." 17

Kamau Bobb recalled how strongly the MEP students and staff were tied in his undergraduate days to faculty of color across the campus, some of whom he named: "[MEP] had intentional and targeted recruitment, structured academic programs and advising once on campus and a place for students of color to feel bolstered if necessary or just at ease in a protected space. The relationship between BGESS and

\footnotetext{
${ }^{15}$ Professor Kamau Bobb, senior director of the Constellations Center for Equity in Computing, Georgia Institute of Technology, personal communication, December 4, 2015.

${ }^{16}$ Sandra Messick, “’We Have a Space!'-Fannie Lou Hamer Black Resource Center Opens,” Berkeley News, February $23,2017$. Internet archived on 2021.01.22.

${ }^{17}$ Milton Howard, Charles Tunstall, and Toni Torres were mentioned, among others, in the tribute in this issue by University-of-Maryland President Darryll Pines, who is mentioned a little further below in connection with MEP.
} 
BESSA was super strong and offered peer-to-peer mentoring and the MEP workshops formalized that in the academic space based on a model implemented by Toni Torres, MEP Director. Then there was the cross-campus strength led by Pedro Noguera and his cohort under the leadership of [faculty] Percy Hintzen and Roy Thomas, ${ }^{18}$ and staff. . . . There was an entire infrastructure that fueled students' desire to come to $\mathrm{Cal}$ and support them once they got there. That surely took at least 20 or so years to build." 19

\section{First African American Rhodes Scholar from Cal}

Dr. Michele deCoteau (BS 1987) was a visible success story for the new MEP Program. A 1988 graduate of Berkeley's Materials Science Department, deCoteau attests to the critical support she derived from both the Minority Engineering Program and the Professional Development Program during her undergraduate years. While at Lowell High School in San Francisco, deCoteau took the BART train daily to join the PDP summer program. One of three African American engineers in her freshman year, she was admitted to materials science with a Regents Scholarship. DeCoteau emphasizes how important it was that MEP included the families of students and assured them that MEP would "take care" of their students academically as advisers and advocates "and that MEP would be a second family." As a freshman, she met Stacy Turner at MEP, and the two remain close friends today. "The African American freshmen stuck together," she says, while looking up to juniors like Darryll Pines. ${ }^{20}$ Charles Tunstall, a former MEP Director, was an

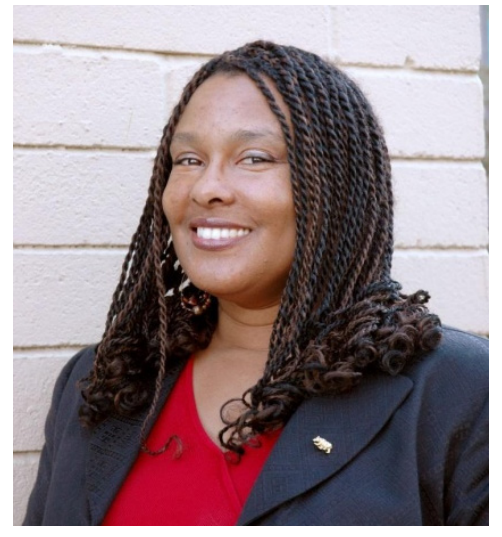

Dr. Michele deCoteau

(Credit: Daily Cal) important influence on deCoteau in both getting into and getting through Berkeley: "Charles was my biggest cheerleader, and that makes a difference in a place like Berkeley."

Dr. Roy Thomas (ethnic studies) and Professor Harry Morrison (physics) approached Michele in her senior year and urged her to apply for a Rhodes scholarship. DeCoteau became the first Berkeley Rhodes Scholar in twenty-five years, as well as the first woman and the first African American ever selected from $\mathrm{Cal}$. She remembers sensing resistance from the campus Rhodes Scholarship selection committee, who apparently had another candidate in mind. At the time deCoteau said that she sought to be a "role model proving that there were Black students doing well in engineering and at UC Berkeley in general." She earned a $\mathrm{PhD}$ in materials science at Oxford in 1993 and taught engineering at a community college. Later deCoteau directed the College of Engineering's Minority Engineering Program with distinction from 1996 to 2010 .

Reflecting on the positive results of the Minority Engineering Program at a 1987 retreat, Dean Pister affirmed "the viability of an affirmative action program in a College where enrollment impaction is very severe." He pointed to the improvement in the graduation rate of MEP students and the rising percentage of students (38 percent by 1987) who were accepted into graduate school. He advocated that the MEP model "ought to be implemented in every engineering school in the United States - for every engineering student!" Dean Pister concluded by telling his audience that the set of elements of a successful MEP "defines a

\footnotetext{
${ }^{18}$ Sociologist Pedro A. Noguera taught at Berkeley from 1980 to 1990 . He currently is the Distinguished Professor of Education at the Graduate School of Education and information studies and faculty director for the Center for the Transformation of Schools at UC Los Angeles (UCLA), Internet archived 2021.01.26. Percy Hintzen was a professor of sociology at Berkeley in the 1980s. Dr. Roy Thomas, Department of Ethnic Studies, was a dedicated mentor to students in the Professional Development Program.

${ }^{19}$ Kamau Bobb, personal communication, 2015. See Dr. Bobb's biography. Internet archived 2021.02.26.

${ }^{20}$ Darryll Pines was named dean of engineering at University of Maryland (UMD), College Park, in February, 2020, and is currently the president of the same university. See the tribute by UMD President Darryll Pines in this issue.
} 
program that is needed by every engineering student. Eventually the Minority Engineering Program would become a Student Engineering Program." 21

\section{The Reentry Program in Computer Science: 1982-1996}

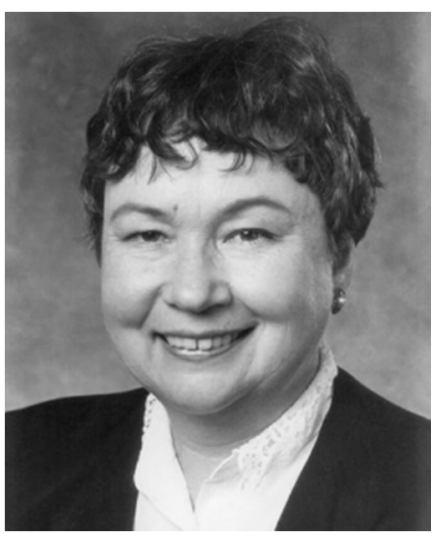

Dr. Paula Hawthorn (Credit: Peg Skorpinski)

In 1982, Dean Pister took the bold stance of supporting the Reentry Program in Computer Science, whose purpose was to prepare postbaccalaureate, "older" women and minorities for competitive admission to graduate school. The program, later called the CS Reentry Program, evolved from a 1978 conference for women in engineering. ${ }^{22}$ Energized by the conference, CS graduate women pushed and negotiated for three years to create a reentry program in computer science at $\mathrm{Cal}$ and a staff position to focus on programs for women. Graduate students Susan Eggers, Paula Hawthorn (CS PhD 1979), and Barbara Simons drafted the proposal for the reentry program, which Dean Pister later circulated to relevant foundations and companies. ${ }^{23}$ The students cited contemporary research that the pipeline of women in computer science was "leaky," because the percentage of women decreased along the way from college to graduate school to full professorships.

Then, as now, women are the largest pool of underutilized workers to meet the needs of the technical workforce. Reflecting on their own situation, the three students envisioned the Reentry Program in Computer Science as tapping into a new demographic: "older" returning students, women, and minorities trained in other fields. Paula Hawthorn recalled that nontraditional students had little chance of gaining admission to graduate school: "We learned that as the enrollment pressure on the department built up, the prerequisites for acceptance into the EECS graduate program became more stringent, so that people who had not followed a standard math/engineering program of study from junior high school had a hard time being accepted into the EECS graduate program. We wanted to give 'non-standard' students, like ourselves, a better chance."

The enrollment pressure on the already impacted undergraduate computer science courses was intense, similar to today's surging demand for the CS

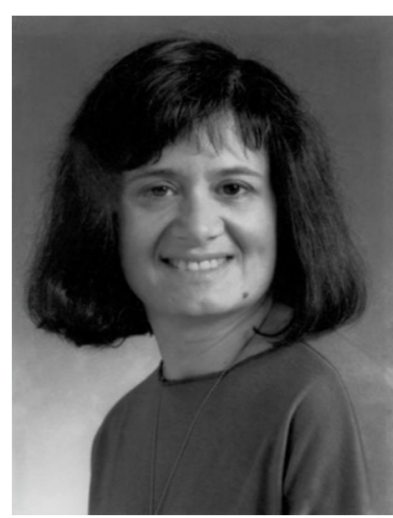

Dr. Barbara Simons (Credit: Peg Skorpinski) major. The activism of Hawthorn and Simons, with support from Dean Pister, resulted in a majority of CS faculty agreeing to the project. Many prominent women computer scientists beyond the Berkeley campus supported the reentry idea and strategized with Hawthorn and Simons ${ }^{24}$ (CS PhD 1981) to gain approval from the CS faculty. Among them were Professor Thelma Estrin of UCLA, a pioneering computer scientist, and Frances E. Allen, the first female to be accorded the honor of IBM Fellow at IBM's Thomas J. Watson Research Center.

\footnotetext{
${ }^{21}$ Dean Karl S. Pister, "Remarks at UC Systemwide Retreat on Graduate Student Affirmative Action” (Asilomar, California, May 20, 1987).

22 The first conference for women in engineering at UC Berkeley was held in 1978.

23 "Reentry Computer Science Proposal for Two-Year Pilot Program" (College of Engineering, UC Berkeley, 1983). Dean Pister initiated the fundraising process by sending proposals to the Westinghouse Foundation, the Alfred P. Sloan Foundation, and others.

${ }^{24}$ See the tribute to then Dean Karl Pister by Dr. Hawthorn and Dr. Simons, together with the Editor's note in that tribute on the short bio of Dr. Simons.
} 
The CS Reentry Program added nontraditional students to classes in an already overcrowded program without bringing new resources to the division. The idea was for industry to assume support of the program. A surprising number of companies signed on early to support the reentry program: Chevron, Textronix, Advanced Micro Devices, AT\&T Foundation, General Electric Foundation, Hewlett-Packard, Honeywell, IBM, Intel, McDonnell Douglas, and NCR Corporation contributed the first year. ${ }^{25}$ Corporate contributions raised the stature of the Reentry Program among the faculty and made it easier to negotiate for student services. The funds were used to pay half-time salary for the program coordinator and student tuition at UC Berkeley Extension.

"There are two good purposes to the reentry program. One is affirmative action, giving opportunities to deserving people who will be good role models for future graduate students. But, further, the program will increase the numbers of Ph.D.'s in CS. At Berkeley we only graduate about nine or ten a year. So many students see the financial advantage of getting a master's but don't want to continue in graduate school. ... The program would be a roaring success if one-quarter of its graduates went into academics." 26

Reentry students brought to the program widely varying backgrounds, from German literature to theater design. Several had worked in tech companies like Lockheed, Varian, and Bechtel. The Reentry Program offered a compressed set of core upper-division courses, which represented a very streamlined version of the undergraduate major. Students spent an average of two years in the program, and some engaged in research projects. The CS Division provided substantial resources, such as computers, equipment loans, seminars, and a special lounge. Berkeley faculty sympathetic to the program individually advised the students and wrote letters of recommendation for graduate school. Women undergraduates and graduate students already at Berkeley encouraged reentry students by tutoring them and coaching them for the Graduate Record Exam (GRE).

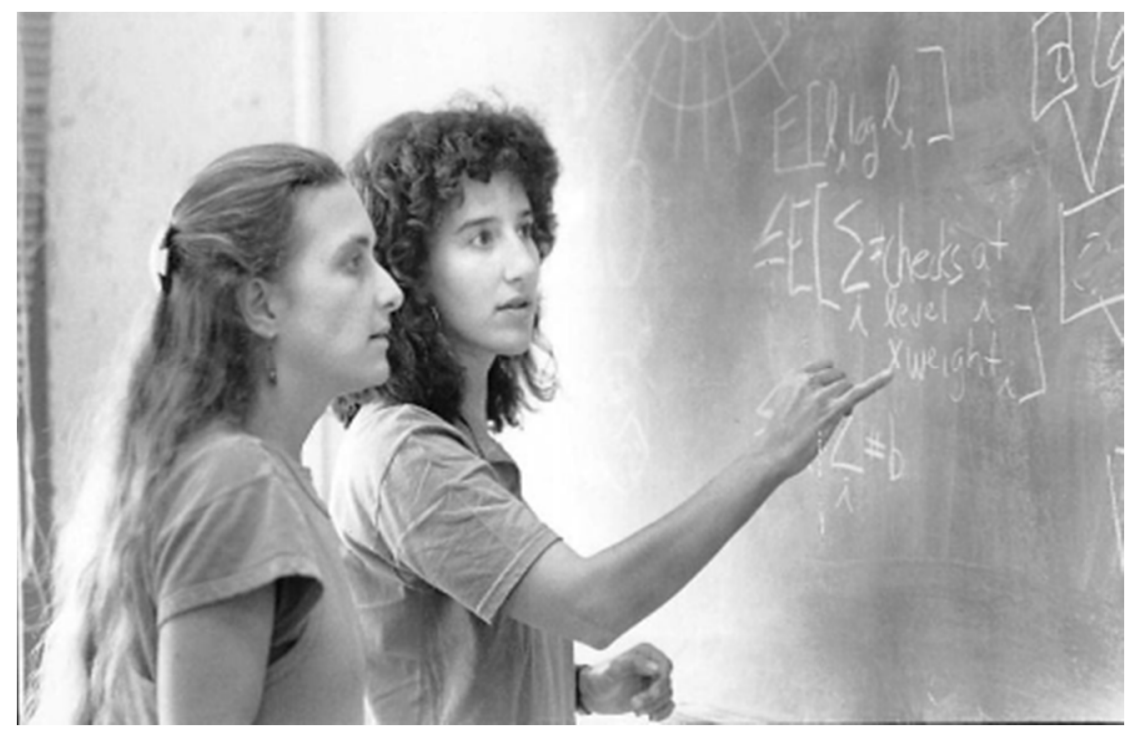

Nina Amenta and Ronitt Rubinfeld, CS doctoral students. Credit: Peg Skorpinski.

Dr. Nina Amenta, now senior professor and former chair of computer science at UC Davis, believes that the program swung open the door to her career: "The reentry program was perfect for someone like

\footnotetext{
${ }^{25}$ On the other hand, the program coordinator was offered three months of half -time salary and was charged with raising the rest.

${ }^{26}$ Professor Eugene Lawler, quoted in Matrix, College of Engineering, UC Berkeley (Fall 1983).
} 
me, with a degree in classics but years of programming experience. Without the reentry program, top graduate schools would never have considered my application and getting into a good school was of course crucial in my becoming a professor myself." 27

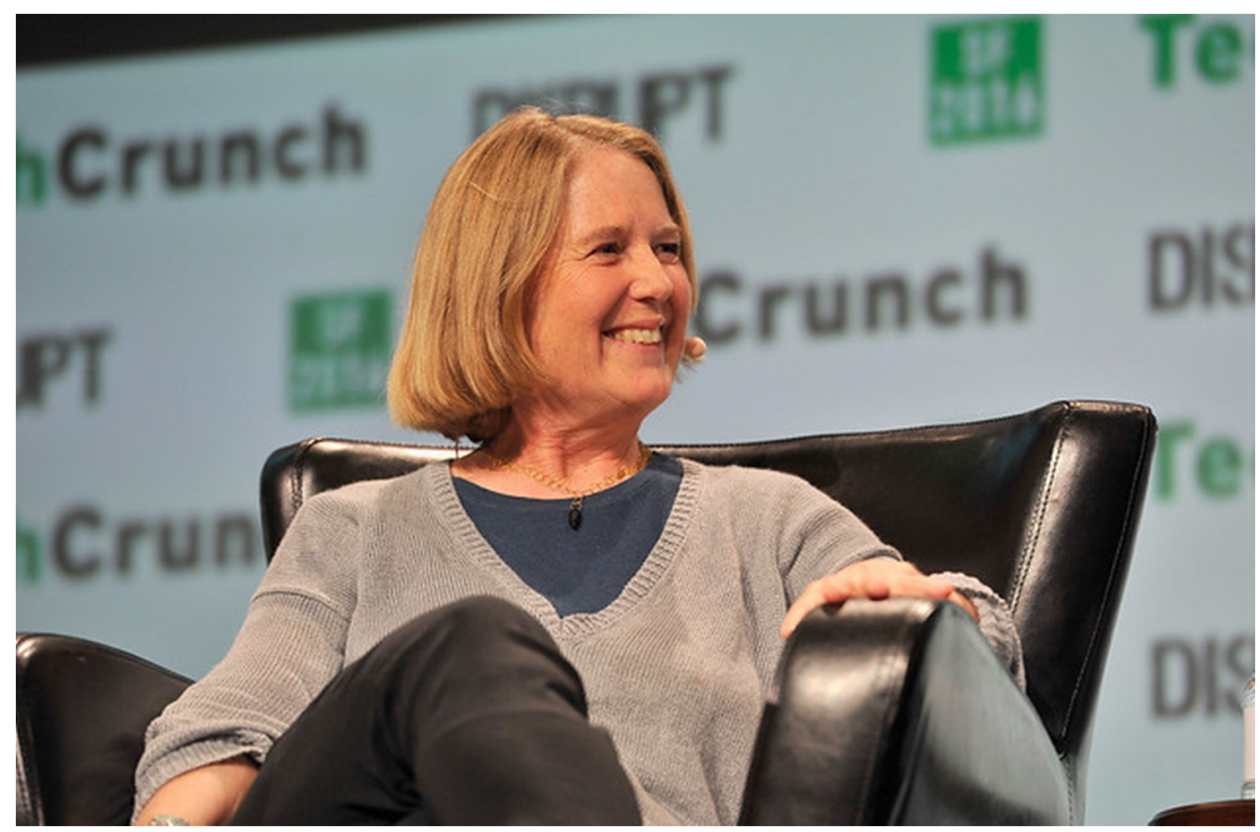

Google Senior Vice President Diane Greene speaking at TechCrunch Disrupt San Francisco 2016 Pier 48 on 2016.09.13. Credit: Steve Jennings, Wikipedia, $\underline{\text { CC-BY-4.0. }}$

Diane Greene is undoubtedly the most famous alumna of the CS Reentry program. Greene called the program "transformative" for her career. After receiving an MS in computer science at Berkeley, she founded a very successful company, VMWARE. Greene is one of the most prominent women in technology. ${ }^{28}$ Greene served as CEO for Google Cloud Computing and returned to Berkeley twice to deliver commencement addresses for both BA graduates in Letters and Science (2016) and BS graduates in the College of Engineering (2018). She was elected into the National Academy of Engineering in 2018 for "contributions in transforming virtualization from a concept to an industry". 29

The quantifiable results of the program include the number of computer science degrees earned and professional positions attained by CS Reentry students now active in the information technology field. These professionals would not have joined the technology work force without the Reentry Program, and they bring to their work the benefit of a broader disciplinary background. (Ironically enough, the rapidly growing new major in data science at Berkeley places a high value on disciplinary breadth. ${ }^{30}$ ) More durable effects of the program include a higher degree of sensitivity to "older" women students in the computing

\footnotetext{
${ }^{27}$ Professor Nina Amenta, UC Davis, quoted in Sheila M. Humphreys and Ellen Spertus, "Leveraging an Alternative Source of Computer Scientists," SIGCSE Bulletin, vol. 34, no. 2 (June 2002). See also 'Nina Amenta', Wikipedia version 05:48, 9 June 2021.

28 Among her many other honors, Diane Greene was named to Data Economy's list “America 50, The World's First Top 50 North, Central and South American Influencers" (November 2018).

29 'Diane Greene', Wikipedia version 19:44, 3 June 2021.

${ }^{30}$ Douglas Belkin, "UC Berkeley's Fastest-Growing Class Is Data Science 101," Wall Street Journal, November 1, 2018: "Berkeley's goal isn't just to train data scientists, but to get students from other disciplines, including the humanities and social sciences, to also learn what a data orientation can do for their work."
} 
community and active recruitment of women into CS, as well as support for the graduate and undergraduate women's groups Women in Computer Science and Engineering (WICSE) and later Association of Women in EECS (AWE). The Computer Science Reentry Program was terminated in 1998, a casualty as a result of the 1996 passage of California's Proposition 209, which prohibits programs at public institutions from providing educational benefits based on gender or ethnicity.

The spirit of the Reentry Program lives on through the influence of its graduates, including several faculty members in computer science. Four years after the conclusion of the CS Reentry Program, a retrospective article summarizing the program's contributions, "Leveraging an Alternative Source of Computer Scientists," appeared in the Association for Computing Machinery's SIGCSE Bulletin. ${ }^{31}$ The presence of nontraditional students during a fifteen-year period has exerted a lasting effect on the culture of computer science at Berkeley by opening the door to a broader group of students.

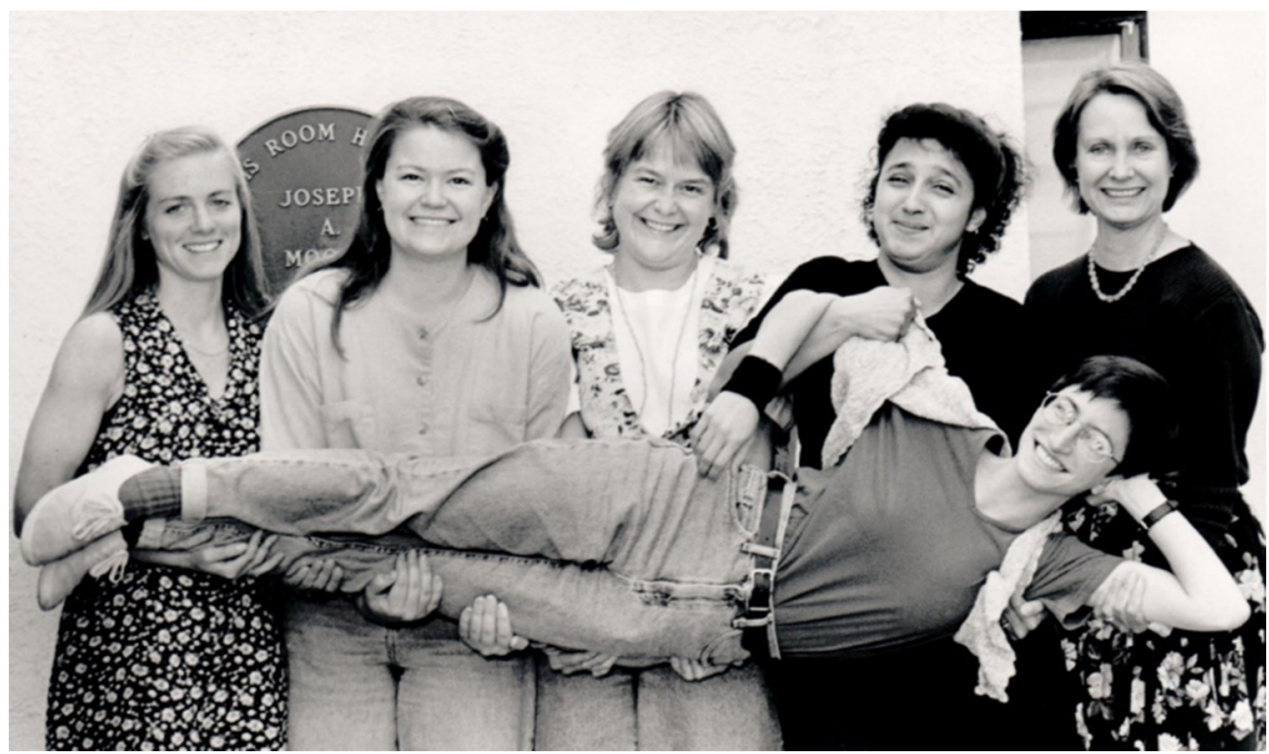

Left to right: Lisa Buckman, Dawn Tilbury, Ginger Ogle, Gitanjali Swamy, Sheila Humphreys, and Ruth Rosenholz (horizontal) at a WICSE lunch meeting, circa 1988. Credit: Peg Skorpinski.

\section{Addressing Graduate Diversity: A New Office of Women and Minority Graduate Matters}

With the Minority Engineering Program in place, Dean Pister turned to diversifying the graduate program by creating the Office of Women and Minority Graduate Student Matters in 1985. Pister appointed me to the new position of half-time academic coordinator for student matters. The associate dean for academic affairs and I were charged with developing and carrying out a plan to attract and support minorities and women. Our mission was twofold: "to intervene in the admissions process with the goal of increasing the number of women and minorities in engineering graduate programs, and to develop programs and policies which create an environment of support for these students in graduate school." Our first action was to draft a graduate-level affirmative action policy for engineering, because none then existed. The policy was approved by the College of Engineering faculty in December 1985. ${ }^{32}$ The Graduate Council of the Berkeley campus did not yet have an affirmative action policy and adopted one at roughly the same time. The

\footnotetext{
${ }^{31}$ Sheila. M. Humphreys and Ellen Spertus, "Leveraging an Alternative Source of Computer Scientists," SIGCSE Bulletin, vol. 34, no. 2 (June 2002).

32 Committee on Graduate Studies, "Memorandum to the Faculty of the College of Engineering," December 3, 1985.
} 
Graduate Council of Berkeley's Graduate Division adopted the new policy: "actively to promote ethnic and gender diversity in the graduate student population through recruitment, admissions, financial aid, and retention programs, and to make continuous effort to improve the success of such activities."

Actively recruiting graduate student applicants was a novel concept, because the College of Engineering already received more than enough applications to ensure a highly selective admissions process. To signal a push for women and minorities, the College produced new brochures with photos of students with whom prospective women and underrepresented students could identify. Faculty and graduate students embarked on recruitment travel to both majority- and minority-serving schools. Staff and students were sent to conduct outreach at key national conferences, such as the National Society of Black Engineers, the Society of Women Engineers, and the Graduate Engineering Minority (GEM) Symposium. When I took my first graduate recruitment trip to Howard University in 1986, Professor Lorraine Fleming, the first Black $\mathrm{PhD}$ graduate of civil engineering at Berkeley the previous year, had been newly appointed at Howard and welcomed me warmly.

\section{"There Is a Perception of Berkeley as Uncaring"}

In March 1986, shortly after the new Office of Minority and Women Graduate Student Matters opened, Dean Pister convened a meeting of minority engineering faculty from across the country. Twelve minority engineering faculty from other institutions agreed to attend. Our purpose was to seek their advice to help us shape the new graduate diversity program. The invited faculty members were urged to discuss frankly how UC Berkeley was perceived and how best to address the resulting challenges of recruiting a more diverse pool. They met for an intense day and a half with deans, the provost, and Berkeley engineering faculty and students, as well as separately as a group. They then attended the College's annual Industrial Liaison Program, featuring technical talks by faculty and graduate students about their research.

After two days at Berkeley, the participants delivered their candid recommendations, which set the context for affirmative action in the seven engineering departments and for the new Office of Minority and Women Grad Matters. Their recommendations are as applicable today as they were in 1986. The thread that ran through their comments was this: "There is a perception of Berkeley as uncaring." Participants identified issues, including the isolation minority students experience, campus climate, bias, and financial aid, but did not explicitly address hiring minority faculty. The participants made three recommendations: (1) individualize the review of applications from minority students; (2) make a commitment to financial support of minority graduate students ("Financial aid packages should be guaranteed to students making satisfactory progress for the length of time it might take to reasonably complete degree"); and (3) support enrolled minority graduate students for success and retention. The visiting faculty members had some general suggestions as well: "Use a personal touch with minorities"; "Have a person who helps negotiate the university system." Other recommendations also centered on breaking down the isolation of students while sensitizing faculty: "Move your new [minority] graduate students together immediately!"; "Efforts should be made to identify and educate faculty members who may have both racial and sexist prejudices." 33

These recommendations from outsiders pushed the College to formulate new approaches. For example, regarding the review of graduate school applications, the suggestion to devote additional scrutiny to applications from minorities and women by admissions committee members was accepted and took hold after 1986. The notion of a closer or "holistic" review is now mandated by the Berkeley Graduate Division in every academic department.

\footnotetext{
${ }^{33}$ Recommendations from participants at the College of Engineering Visiting Minority Faculty Meeting, March 1986.
} 
Six weeks after receiving comments from the College of Engineering Visiting Minority Faculty Meeting, the College's Committee on Graduate Study issued a memo to the College of Engineering faculty that restated insights gained from the March meeting. Among their recommendations were a recalibration of admissions criteria and much more focus on supporting students once they were admitted and had entered the university.

\section{Results of the Graduate Initiative}

Within two years, engineering departments attracted more minority graduate students. MEP Director Charles Tunstall invited the then director of the Graduate Engineering Minority (GEM) Consortium to talk to Berkeley undergraduates about applying to graduate school. The personal dynamism of this GEM Consortium director made him very influential in motivating students to attend graduate school. Milton

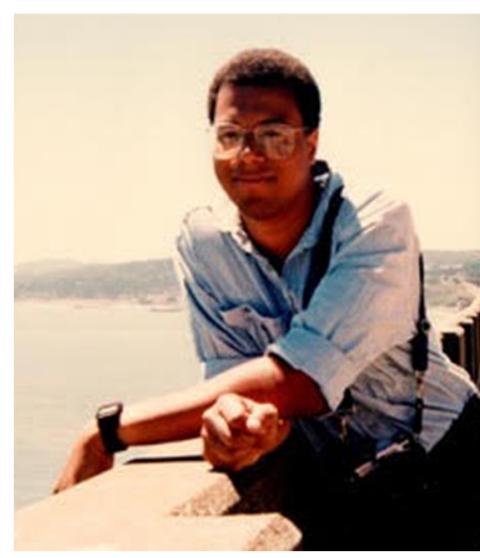

Professor Andrew Meade Howard (BS 1986) attended that talk when he was a junior and recalls, "We left that meeting pretty focused, pretty excited.... Our eyes were opened to something we never considered. Most of us were firstgeneration college students." 34 Many minority graduate students in the College of Engineering were initially funded through a Graduate Engineering Minority (GEM) Master's Fellowship.

Professor Andrew Meade of Rice University, who was a GEM Fellow in the 1980s and graduated in June 1989 (left inset photo, taken in the Bay Area right after his graduation), reflected on his GEM fellowship: "I was fortunate enough to secure a GEM graduate fellowship at the MS level and was accepted to the mechanical engineering program. I loved the atmosphere and support so much that I stayed on for the $\mathrm{PhD}$ program. With the aid and funding from the MEP, I was able to graduate, and to move on to a career in academia. I'm presently a professor at Rice University in mechanical engineering and run the aerospace educational program. I also served as department chair, among other posts at the university. I credit the GEM Fellowship and am forever grateful to the hardworking and supportive MEP staff." 35

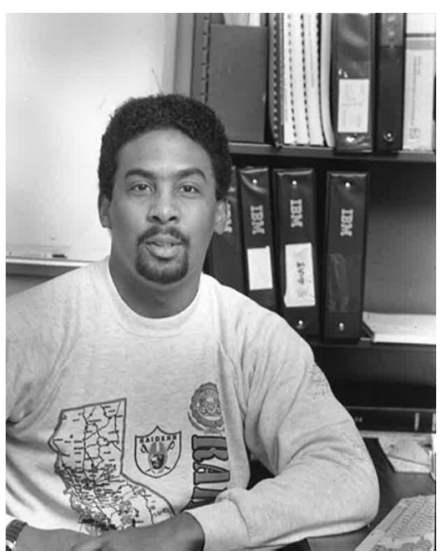

Dr. Colin Parris

(Credit: Peg Skorpinski)

Dr. Colin Parris of General Electric (inset photo, right, when he was a graduate student in CS in 1988, credit: Peg Skorpinski) and Professor Jeffrey Streator of Georgia Institute of Technology were also GEM Fellows among others.

Berkeley began sending faculty and minority graduate students to recruit at minority-serving universities and colleges, as well as regularly sponsoring students at minority conferences such as the National Society of Black Engineers (NSBE). The College of Engineering tripled the overall number of

\footnotetext{
${ }^{34}$ Milton Howard obtained an MS at the University of Michigan. Milton Howard, personal communication, May 16, 2018. See also Footnote 12 in relation to the tribute by University of Maryland President Darryll Pines.

35 Professor Andrew Meade also contributes a technical article in this Karl Pister Special Issue.
} 
minority students, from nine to twenty-seven, within one year. ${ }^{36}$ A group of Black graduate students founded the Black Graduate Engineering and Science Students (BGESS) organization in 1986, which has helped not only to provide peer support but also to influence policy and practice in the academic departments. BGESS thrives today, thirty-four years after its founding, by creating community and peer support for African American students in STEM, and assistance with recruitment.

\section{A Daunting Challenge: Diversifying the Faculty}

Dean Pister pursued the challenge of diversity on the engineering faculty throughout his decade as dean. In 1980 Professor Susan Graham (computer science) was still the sole tenured female faculty member in the College of Engineering. The dean extended strategic invitations to the most distinguished women and minority engineers in the nation for short-term visits. These role models served as existence proofs for students, and for the faculty as well. In Dean Pister's first six years, the College of Engineering appointed six women professors on the tenure track, although none was hired in EECS. ${ }^{37}$

The College collaborated closely with the departments in initiating invitations to prominent engineers from diverse backgrounds: for example, the McKay Endowment in EECS, the Computer Research Association's Visiting Lecturer Program, the Office of the President Regents' Lecturers, and Berkeley Chancellor's Professorships. These short visits, for several days or a few weeks, enabled highly visible women to interact intensely with students and faculty. Pister actively leveraged the program to invite to campus prominent women members of the National Academy of Engineering such as Professor Mildred Dresselhaus of the Massachusetts Institute of Technology (MIT) and Dr. BetsyAncker Johnson, a vice president at General Motors. Ancker-

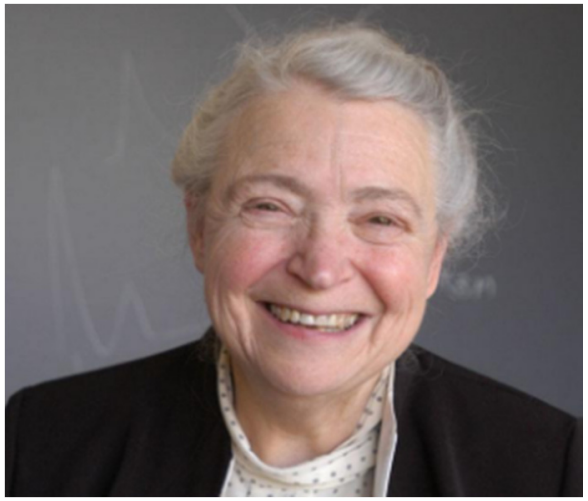

Professor Mildred Dresselhaus Johnson held a $\mathrm{PhD}$ in physics from Berkeley and had served as U.S. undersecretary of commerce.

Mildred Dresselhaus and Ancker-Johnson were the only living female members of the National Academy of Engineering (NAE) at the time. Dresselhaus was the third woman engineer elected to the NAE, in 1974, and Ancker-Johnson, elected the following year, was the fourth. EECS also hosted IBM Fellow Frances E. Allen, a pioneer in the field of compilers, as a visiting scholar. Dean Pister advocated for Allen in a memo to Chancellor Heyman in 1987: "Allen will not only serve as a tremendous resource to the academic and research efforts of the Department, but she will also play an urgently-needed role model for aspiring female students both in the EECS Department and the College at large." Allen was the first woman to receive the Turing Award in 2008. ${ }^{38}$

\section{Visiting Women Professors}

During the 1980s Mary Ryan, a progressive National Science Foundation (NSF) program officer, started funding programs to attract and support women in science. In 1982 NSF had initiated Visiting Professorships for Women (VPW), lasting a few weeks or upto a year, to address the lack of role models

\footnotetext{
${ }^{36}$ Karl S. Pister and Sheila M. Humphreys, Affirmative Action Report, Office of Women and Minority Graduate Student Matters, College of Engineering, University of California, Berkeley, 1986.

${ }^{37}$ Avideh Zakhor joined the EE faculty in 1987 as the first woman faculty member in electrical engineering and the second woman faculty member in EECS.

${ }^{38}$ Association for Computing Machinery, “A.M. Turing Award: Frances ('Fran') Elizabeth Allen”.
} 
in science and engineering and "the resistance women encountered in trying to excel in male-dominated fields." ${ }^{39}$ VPW awardees could not already be full professors, or at the zenith of their careers like the Regents' and Chancellor's appointees, but were at levels at which the Berkeley visit could advance their own careers. The visiting women, who stayed for two weeks, were required to interact with and encourage female students as well as carry out their proposed research. The EECS Department welcomed three VPW faculty grantees of this competitive program. In each case, the stint at Berkeley led to advancement for the women in their home institutions.

Dr. Jeanne Ferrante was awarded the first NSF VPW in 1985. A computer scientist at IBM's Thomas J. Watson Research Center, Ferrante spent an academic year at Cal. A member of Frances E. Allen's group at IBM Research, Jeanne taught a graduate class on parallel computing to sixty Berkeley graduate students and implemented a series of workshops titled "On Being a Researcher." ${ }^{\text {" }}$ Professor Ferrante organized a panel to talk about what it is like to do research. Students were totally surprised and reassured, a senior professor admitted he "didn't know what he was doing all the time, and where his research was going." Ferrante later accepted a faculty job at UC San Diego and became the first female chair of electrical and computer engineering there.

The NSF chose Berkeley to host two additional professors under the VPW program: Mary Lou Soffa, from the University of Pittsburgh, and Dr. Ljiliana Trajkovic, member of the technical staff at Bell Labs. Dr. Soffa later moved to the University of Virginia, where she led the Computer Science Department as chair. The Berkeley appointment was instrumental in helping Dr. Trajkovic to make a subsequent transition from Bell Labs to a faculty appointment at Simon Fraser University, where she has tenure. In 1987 the EECS Department hired a second woman, Professor Avideh Zakhor, who was the first female faculty member in electrical engineering. During Dean Pister's decade in office, seven women were hired on the faculty.

\section{Faculty of Color at Berkeley in the 1980s}

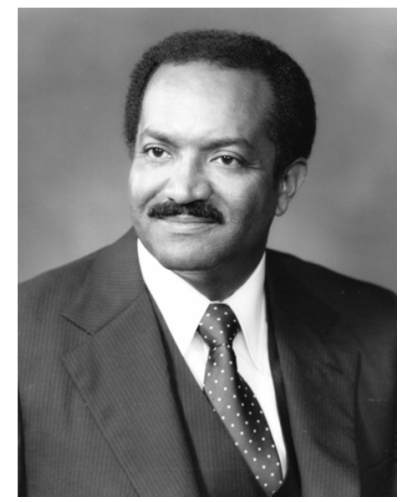

Dr. Percy Pierre VFS (CC BY-SA 4.0)
Hiring faculty of color presented a far more daunting task than hiring women faculty. As Dean Pister stated in his oral history, the dean can "take the moral high ground" but faculty search committees make the choice of whom to hire.

In the absence of minority faculty in engineering, the dean used the same strategy as for women, by inviting distinguished engineers for short academic visits, in order to give students and colleagues exposure to successful role models. Among them were Dr. Victor Lawrence (AT\&T Bell Labs); Professor John Foster, North Carolina Agricultural and Technical State University; Dr. Sandra Baylor Johnson, IBM Research; and Dr. William Velez, University of Arizona. Dr. Percy Pierre, a widely recognized leader in STEM education, former president of Prairie View A\&M University, and former dean of Howard University, served as Regents' Lecturer in $1990 .{ }^{41}$ At Berkeley, he met with Black graduate students and gave a lecture, "Improving Math/Science

\footnotetext{
${ }^{39}$ Ruckus and Williamson, The VPW Program: Lowering the Hurdles for Women in Science and Engineering, Washington, DC, April 1994.

40 Jeanne Ferrante gave a lecture during her VPW visit on The Importance of Failure, in which she discussed the value of failure to advance one's research, using Richard Feynman's analysis of the failure of the Apollo shuttle.

${ }^{41}$ Dr. Percy Pierre earned his PhD in electrical engineering from Johns Hopkins University in 1967 and was the first African American to earn a doctorate in that field. He was vice president for research and graduate studies at Michigan State University (MSU) at the time of his visit in 1990.
} 
Education in Urban Schools." Not until the decade following Dean Pister's tenure, in 1996, was the first African American professor hired in the Department of Electrical Engineering and Computer Sciences.

\section{Chancellor of UC Santa Cruz}

After completing his term as dean, Karl Pister was almost immediately asked by the president of the university, David Saxon, to take on service as interim chancellor of UC Santa Cruz. After a year he was appointed chancellor, a post he held until 1996. At Santa Cruz, Chancellor Pister worked to expand existing outreach programs, particularly with $\mathrm{K}-12$ schools and the community college system. The work was interrupted by the Regents' adoption, in July 1995, of Special Policy 1 (SP1) and Special Policy 2 (SP2) ending the use of race, ethnicity, and gender as factors in admissions, contracting, and hiring. A detailed account of Pister's years as chancellor of UC Santa Cruz may be found in his oral history there. ${ }^{42}$

\section{"The Conscience of the Upper Administration"}

Up to the present Karl Pister has actively continued to give his time and wisdom in a variety of roles to advance access to the university. Some of his contributions are visible, but many have been behind the scenes.

In the wake of the Board of Regents' July 1995 vote to end racial and ethnic preferences in admissions, a systemwide Outreach Task Force was created and charged with developing a strategic plan to protect UC's diversity in the new postaffirmative action world. Pister served first as a consultant to the Outreach Task Force; later, at UC President Richard Atkinson's request, Pister agreed to serve as vice president for educational outreach. Berkeley Provost Emeritus Paul R. Gray ${ }^{43}$ was dean of engineering in the period following the passage of Proposition 209 in 1996. He remembers Pister's critical leadership at that fraught time for the university: "Karl Pister's long career in academic leadership has been remarkable for many reasons, but his lifelong commitment to access and inclusion really stands out. He created the groundwork for much of the array of programs that have helped address this issue at Berkeley both in engineering and more broadly. His leadership during those difficult years in the 1990s at UCOP [UC Office of the President] as Vice President were critical in helping the UC system find its way and realize the importance of broad outreach

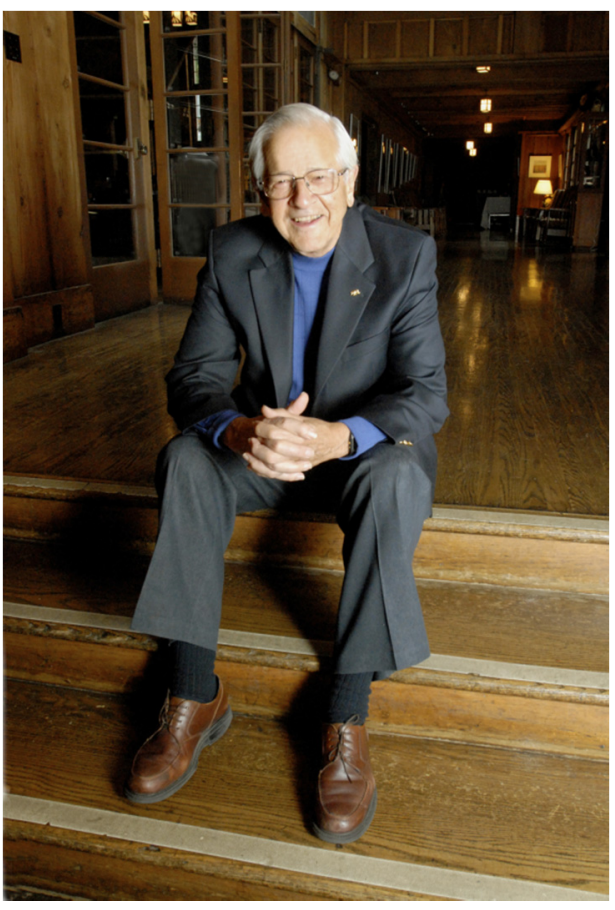

UCSC Chancellor Karl S. Pister

(Credit: Peg Skorpinski) and inclusion in its role as the leading public university system in the country. He provided an important part of the conscience of the upper administration at Berkeley and in the UC system in his various leadership roles. We all owe Karl a great debt for that.",44

Working closely with his campus and UCOP colleagues, Pister oversaw implementation of the Task Force's recommendations and coordinated campus and systemwide programs to attract more educationally

\footnotetext{
42 “Karl S. Pister: UCSC Chancellorship, 1991-1996," Institutional History of UC Santa Cruz, 2000.

${ }^{43}$ Paul Russell Gray was chair of the Department of Electrical Engineering and Computer Sciences (1990-1993), dean of the College of Engineering (1996-2000), and executive vice chancellor and provost (2000-2006) at UC Berkeley.

44 Provost Emeritus and Professor of Electrical Engineering Paul R. Gray, personal communication, February 2019.
} 
disadvantaged students to UC campuses. He saw the outreach initiative as an opportunity for a new landgrant model to complement the old: cultivating the rich talent of California's young people through UC partnerships with K-12 schools, principals, teachers, students, and underserved communities. Pister's leadership was critical to the early success of the most ambitious outreach enterprise the university has ever undertaken. Generous state funding made it possible to realize a number of the Outreach Task Force's goals before the economic downturn of the early 2000s drastically curtailed UC's efforts.

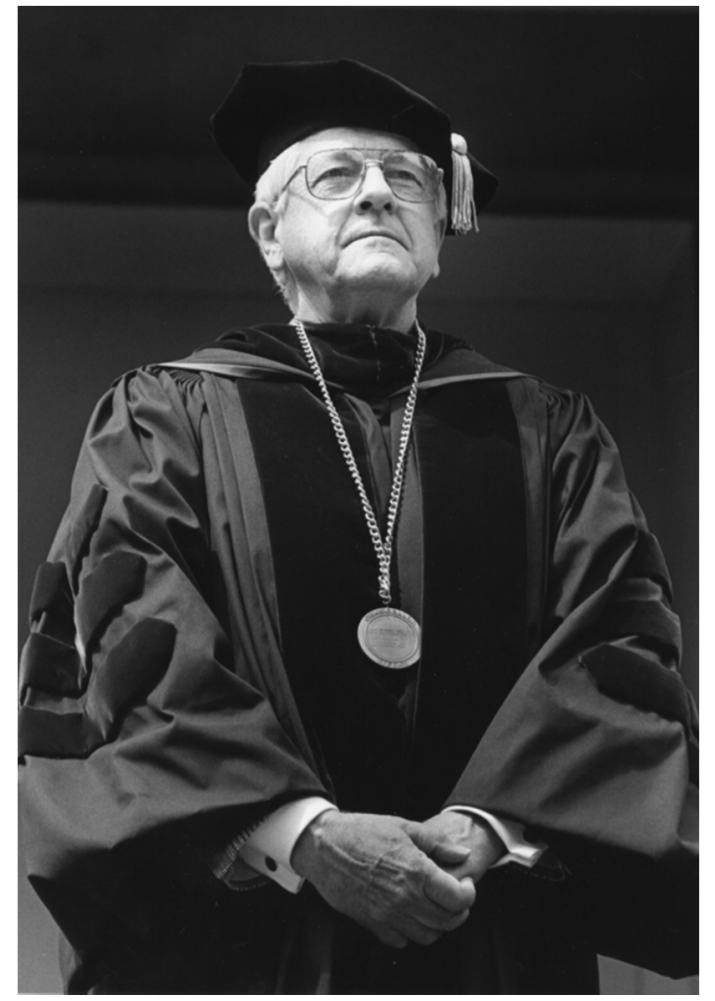

UCSC Chancellor Karl S. Pister

For two years, Pister served on the Regents Task Force on SP1 and SP2. ${ }^{45}$ Then, from 2002 to 2004, he directed the Center for Studies in Higher Education at Berkeley. In a final assignment, Chancellor Robert Birgeneau appointed Pister in 2004 as the chancellor's senior associate to oversee a major capital program, the Southeast Campus Integrated Projects. In this role, Pister agreed to chair the task force on upgrading California Memorial Stadium - a commitment he carried out for eight years, until 2012. ${ }^{46}$

Karl Pister continues to engage in purposeful conversations with colleagues. He provides sage advice and mentoring based on more than sixty years of dedicated service to the University of California. President Emeritus Richard Atkinson summed up Pister's enormous contributions to the University of California: "In many different ways and in many different roles, Karl Pister has led by example and helped shape the values of his profession and the culture of our academic community. His contributions reflect a passionate commitment to promoting social justice, a commitment that continues undiminished to this day. Few individuals in the history of the University of California have served it so long, so devotedly, or so well." 47

(Credit: Peg Skorpinski)

Sheila Humphreys, $\mathrm{PhD}$

Co-Chair 150W History Project

https://150w.berkeley.edu (Internet archived on 2021.06.28)

Emerita Dir. of Diversity, EECS Dept, UC Berkeley

EECS Notable Women: Sheila Humphreys $\mid$ EECS at UC Berkeley (Internet archived on 2021.01.23)

\footnotetext{
45 John A. Douglass, A Brief on the Events Leading to SP1, February 28, 1997.

${ }^{46}$ This assignment proved to be onerous in terms of town-gown conflicts. The committee met weekly during those years. They dealt with lawsuits from the City of Berkeley and Save the Oaks. Protesters perched high in the California live oak trees for twentyone months, halting construction. Sylvia McLaughlin, widow of the first dean of engineering, Donald O. McLaughlin, and an ardent conservationist, was one of the tree sitters. See "Tree-Sitters Descend from Redwood to End Protest Peacefully," UC Berkeley News, September 9, 2008.

${ }^{47}$ Richard C. Atkinson, personal communication, January 2019.
} 